\title{
2. SITE 353: VEMA FRACTURE ZONE
}

The Shipboard Scientific Party'

With an Additional Report From

David E. Fisher, Rosenstiel School of Marine and Atmospheric Sciences, Miami, Florida

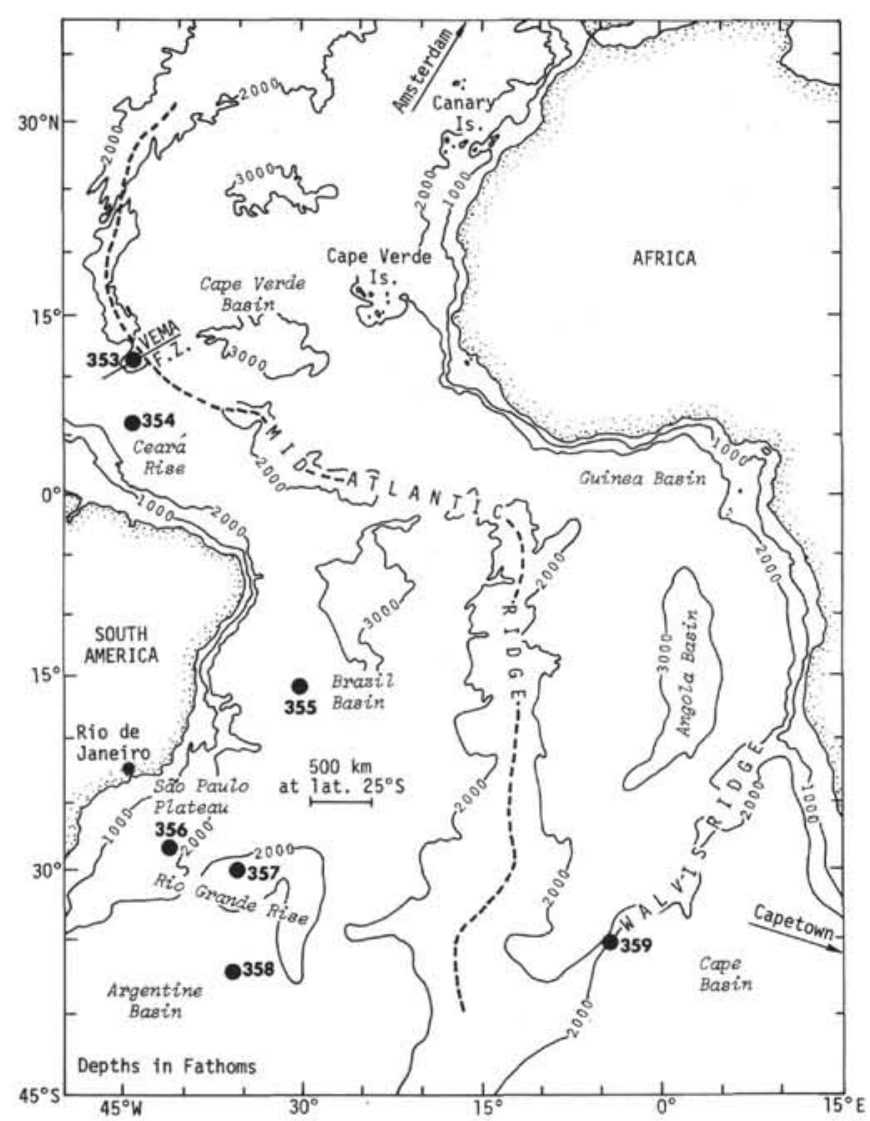

SITE DATA

Date Occupied: 21 October 1974 (1055Z)

Date Departed: 25 October 1974 (0003Z)

Time on Site: 3 days, 13 hours

Position:

Hole 353 : $10^{\circ} 54.90^{\prime} \mathrm{N}, 44^{\circ} 02.25^{\prime} \mathrm{W}$

Hole 353A: $10^{\circ} 55.39^{\prime} \mathrm{N}, 44^{\circ} 02.21^{\prime} \mathrm{W}$

Hole 353B: $10^{\circ} 55.49^{\prime} \mathrm{N}, 44^{\circ} 02.29^{\prime} \mathrm{W}$

Accepted Water Depth: 5167 meters (drill pipe measurement)

'K. Perch-Nielsen, Eidg. Technische Hochschule, Zürich, Switzerland (Co-chief scientist); P.R. Supko, Scripps Institution of Oceanography, La Jolla, California (Co-chief scientist); A. Boersma, Lamont-Doherty Geological Observatory, Palisades, New York; E. Bonatti, University of Miami, Miami, Florida; R.L. Carlson, University of Washington, Seattle, Washington; F. McCoy, LamontDoherty Geological Observatory, Palisades, New York; Y.P. Neprochnov, U.S.S.R. Academy of Sciences, Moscow, U.S.S.R.; H.B. Zimmerman, Union College, Schenectady, New York.
Penetration: 384.5 meters

Number of Holes: 3

Number of Cores: 5

Total Length of Cored Section: 23.5 meters

Total Core Recovered: 9.6 meters

Principal Results: We drilled three holes at Site 353 near the north wall of the Vema Fracture Zone, but did not achieve the primary goal, penetration of basement. We abandoned Hole 353 at 384 meters, in Pleistocene turbidite sediments, because the Bowen drilling subassembly failed. In Holes $353 \mathrm{~A}$ and $353 \mathrm{~B}$, we were unable to penetrate a basalt cobble layer, at least 13 meters thick, which underlies 168 meters of turbidite sediments; so we had to abandon these holes as well. Sediments collected indicate that the wall of the fracture zone has itself been a sediment source, in addition to the Amazon Cone area, which provided the bulk of the material.

\section{BACKGROUND AND OBJECTIVES}

The composition of the oceanic lower crust is one of the outstanding unresolved questions in marine geology. The main objective of drilling at Site 353 was to obtain a section of material from the lower oceanic crust, beneath the basalt layer (layer 2). Sampling the lower crust (layer 3) directly is difficult, because it is overlain by $1-2 \mathrm{~km}$ of basalt plus unconsolidated sediment. To drill through such thickness of basalt would strain, and might exceed, the present capabilities of Glomar Challenger.

The reason for attempting to core lower crustal rocks at Site 353 is that some of the large fracture zones which intersect the Mid-Atlantic and Mid-Indian ridges may provide windows into the lower crust: lower crustal material may be exposed on the slopes of the deep troughs that mark these fracture zones. So by drilling at appropriate sites in one of the fracture zones, it may be possible to bypass completely the basalt layer (layer 2 ) and drill directly into the lower crust.

One serious objection to this approach is that the oceanic crust within offset zones may be "anomalous," in the sense that some limited but significant crustal generation, with production of material different from that created at the ridge axis, may take place in "leaky" offset zones. We tried to overcome this objection by choosing a site west of the north spreading axis on the northern wall of the Vema Fracture Zone.

\section{Vema Fracture Zone}

The Vema Fracture Zone, which offsets the MidAtlantic Ridge about $300 \mathrm{~km}$ at $11^{\circ} \mathrm{N}$ (Figure 1), is 


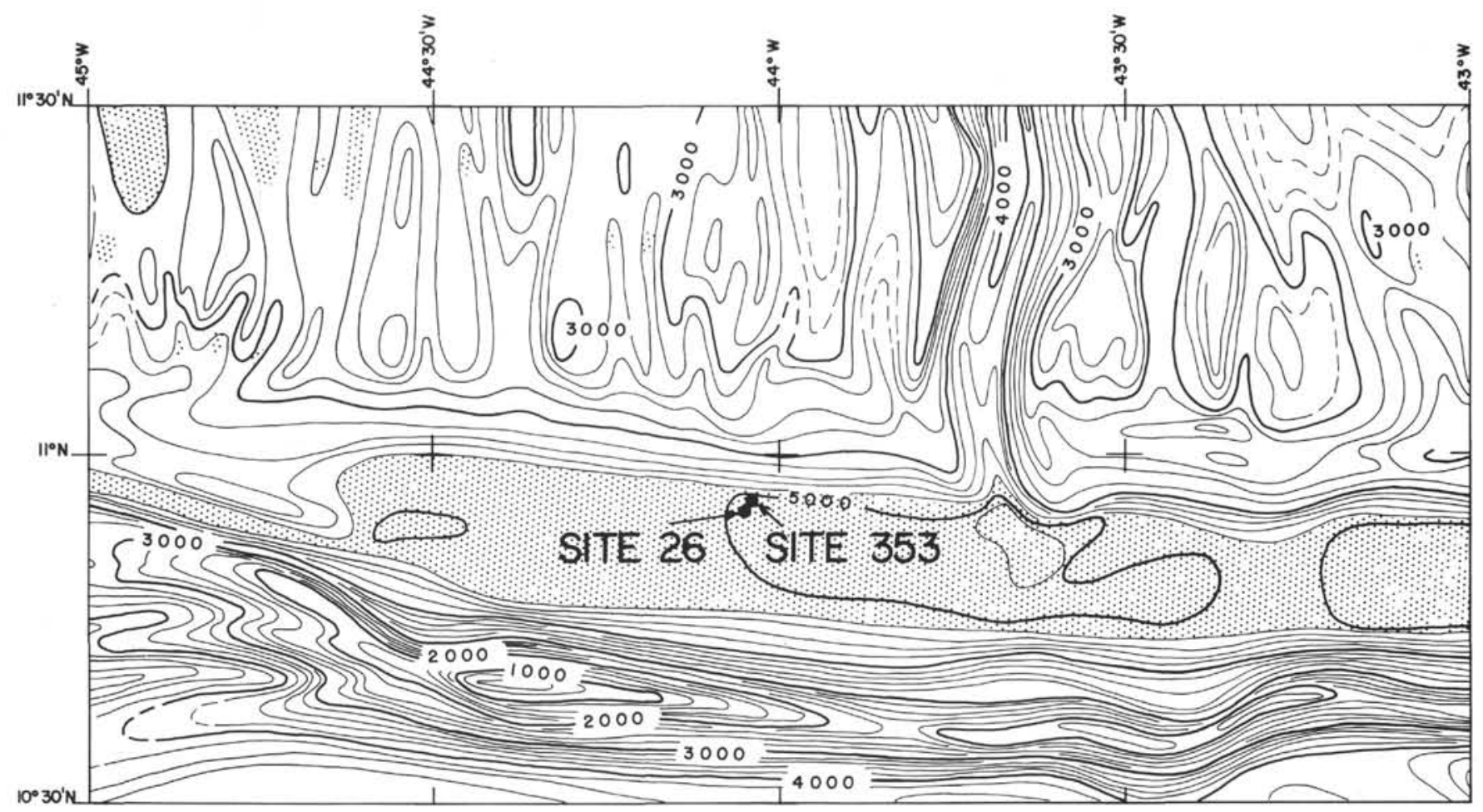

Figure 1. Bathymetric chart (from van Andel et al., 1971) of a portion of the Vema Fracture Zone showing the location of Site 353 .

relatively well known topographically and petrologically (van Andel et al., 1967, 1971; Melson and Thompson, 1971; Bonatti et al., 1971; Bonatti, 1973; Robb and Kane, 1975). The axial segment of the MidAtlantic Ridge north of the offset zone is interrupted abruptly by a transverse trench or valley, whose floor is more than $5 \mathrm{~km}$ below sea level (Figure 2). This valley contains sediments about $1 \mathrm{~km}$ thick (drilled by Glomar Challenger at Site 26 during Leg 4) which consist mainly of Pleistocene turbidites derived from the Amazon Cone.
A steep transverse (east-west) ridge runs parallel to the transverse valley and constitutes its southern wall; it reaches 600 meters below sea level. This ridge appears to consist primarily of serpentinized peridotite and may represent a diapirically emplaced body of upper mantle material.

The northern wall of the Vema transverse valley consists, by contrast, of exposed crustal sections, roughly 2-3 km thick; basalts prevail in the upper portion of the slopes, gabbros, metagabbros, and serpentinized peridotites in the lower portions (Figure 3).

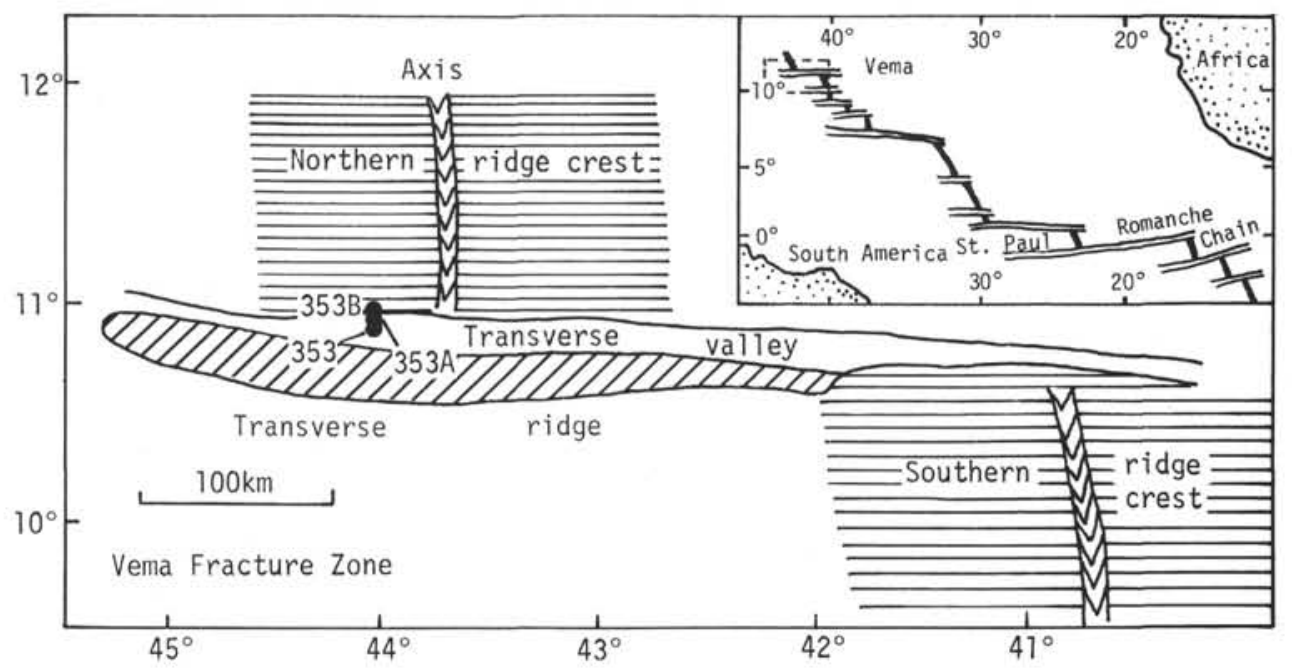

Figure 2. Generalized morphological provinces of Vema Fracture Zone, after van Andel et al., 1967. 


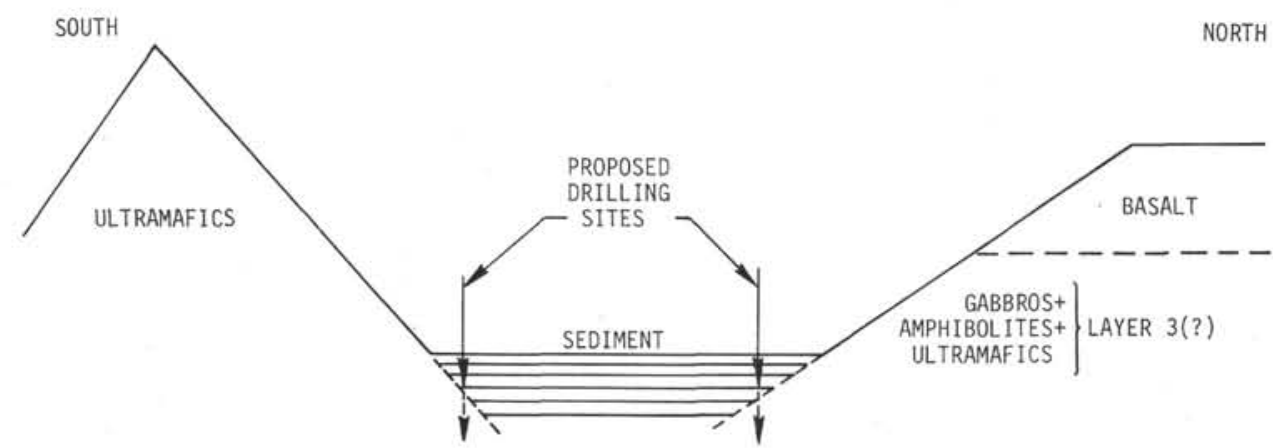

Figure 3. Schematic and qualitative section through the Vema Fracture Zone based upon topographic data and reflection profiles by van Andel et al., 1967, and on petrographic data of the Rosenstiel School of Marine and Atmospheric Sciences. Proposed drilling sites are shown both to drill into layer 3 and to drill into the presumed serpentinite body.

Measurements of densities and compressional wave velocities in rocks dredged from this section (N.I. Christensen, unpublished) indicate that the physical properties of rocks from the lower portion of the crustal section under discussion do indeed fit those expected for layer 3 material.

The objection that this crustal section may be anomalous can be overcome as follows. Composition of basalts from the northern axial segments of the MidAtlantic Ridge up to the very edge of the east-west trench that marks the offset is within the normal range of abyssal tholeiites. Basalts from crustal sections on the northern wall of the trench, within the offset zone, have similar composition and are undistinguishable from the ridge axis basalts. This, and age determinations on these basalts, suggests that they were originally emplaced at the northern axis of the ridge, and that crustal spreading occurred normally up to the very edge of the offset zone (Bonatti et al., 1975). Thus, it appears that the crustal section exposed on the northern wall of the east-west trench is representative of a normal upper crustal section for this region of the Atlantic, and that the upper part of layer 3 is probably exposed in these sections.

It was originally proposed that Glomar Challenger drill at two sites in the Vema Fracture Zone: one close to the foot of the northern wall, in order to obtain, if possible, a "normal" section of the lower oceanic crust; and another close to the foot of the southern wall, in order to obtain a section from a mantle-derived serpentinite intrusion. The locations of the proposed sites are shown schematically in Figure 3. Because of lack of time, the attempt into the southern wall was not carried out during Leg 39.

In drilling at Site 353 , we attempted to penetrate the sea floor close to the bottom of the northern slope of the transverse valley, so as to go through $100-200$ meters of sediment (required to stabilize the bottomhole assembly), and to drill into basement, as indicated in Figures 3 and 4.

Since the lower oceanic crust is probably very heterogeneous and horizontally layered, it was desirable to obtain as long a section as possible. Time limitations prevented use of the re-entry capabilities of
Glomar Challenger at this site; so maximum penetration was to be attempted without re-entry, and the limiting factor was expected to be wear on the bit.

\section{OPERATIONS}

We approached the Vema Fracture Zone on a course of $215^{\circ} \mathrm{T}$, to a point at $11^{\circ} 05.0^{\prime} \mathrm{N}, 43^{\circ} 21.5^{\prime} \mathrm{W}$, where we began site surveying. We changed course to $195^{\circ} \mathrm{T}$ and reduced speed to 6 knots, to obtain a profile down the north wall and into the sediment-filled valley at a point 15 nautical miles east of the north spreading axis. The steepness of the wall here was, we thought, too great for us to locate accurately the thickness of sediments desired (approximately $150 \mathrm{~m}$ ), so we decided to proceed to a point on the north wall, west of the north spreading axis, on a profile line of van Andel et al. (1967), on which Site 26, Leg 4, was located. Accordingly, we changed course to $275^{\circ} \mathrm{T}$. Figure 5 shows the ship's track in the site vicinity, and Figure 6 shows the approach profile. Several crossings of the steep north wall and wall-valley contact were necessary before we could select a site. In Figure 5, assumed ship's track between satellite fixes is adjusted by using bathymetry and regional trends as a guide.

At $1055 \mathrm{Z}$ we dropped a $16-\mathrm{kHz}$ beacon at a point calculated to be some 750 meters south of the foot of the north wall (taking into account distortion of the profile trace because of steepness and side echoes). We retrieved gear and returned over the beacon. The final location of Site 353 is $10^{\circ} 54.90^{\prime} \mathrm{N}, 44^{\circ} 02.25^{\prime} \mathrm{W}$. The water depth by drill pipe measurement is 5167 meters (accepted as true depth), and by PDR, 5165 meters, corrected.

We accomplished final beacon lock-on at 1325Z, after losing some 2-1/2 hours because of problems associated with ship's power and beacon positioning system. A through-hull piccolo was installed, pipe was run, the heave compensator and Bowen subassemblies were picked up, and the hole was spudded at $0825 \mathrm{Z}, 22$ October. Although the core barrel pinger failed during the running of pipe, firm bottom was felt at 5167 meters water depth, and a surface piston core was cut. The retrieval attempt found the core barrel jammed in the pipe; attempts to free it caused the overshot shear pin to 


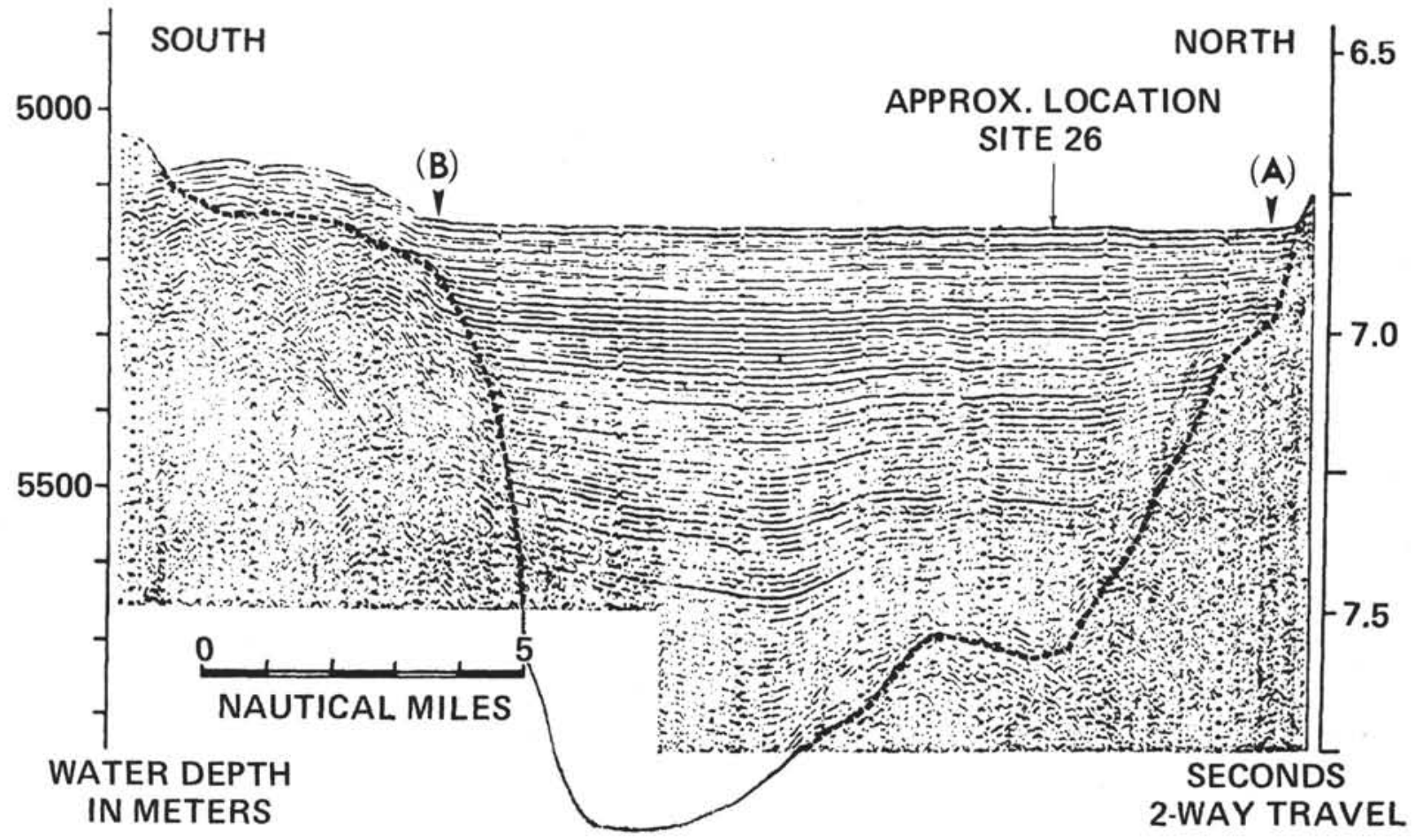

Figure 4. Reflection profile (from van Andel et al., 1967) across the Vema offset. Location of Site 26, Leg 4 is indicated-(A) and $(B)$ are sites for holes suggested for Leg 39 drilling.

fail. A second overshot was sent down and the core was retrieved. Pumping during the attempts to free the core barrel caused loss of the core, except for a 1-cm sample on the piston. The hole was washed to a depth of 118.5 meters, where Core 2 was cut (Table 1 ). Washing continued down to a hard layer, at 261.0 meters, which was cored. We hoped that we might encounter basement or a breccia of igneous rocks, but the formation became

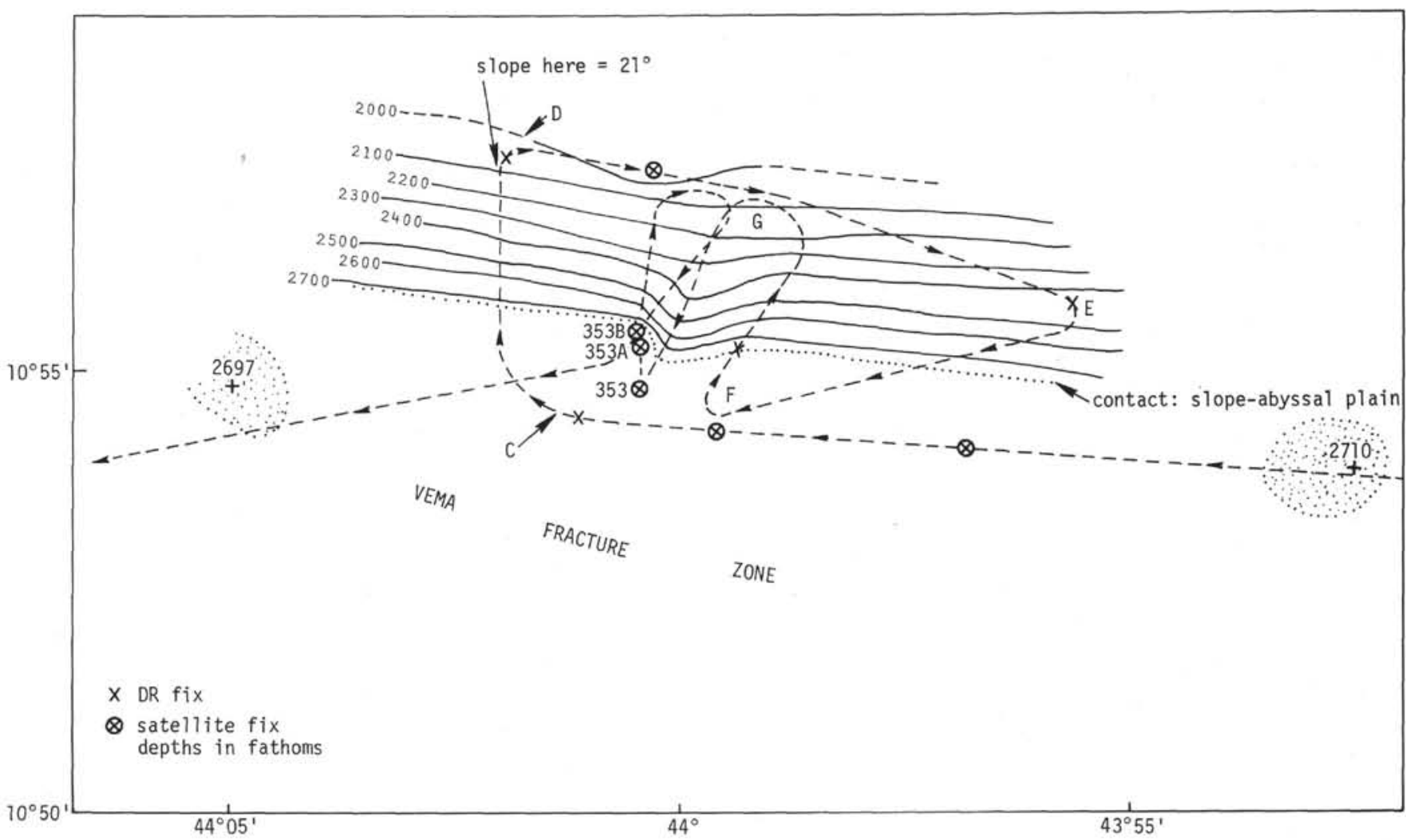

Figure 5. Glomar Challenger track in the vicinity of Site 353. Letters refer to major course changes which are also shown on Figure 6. 


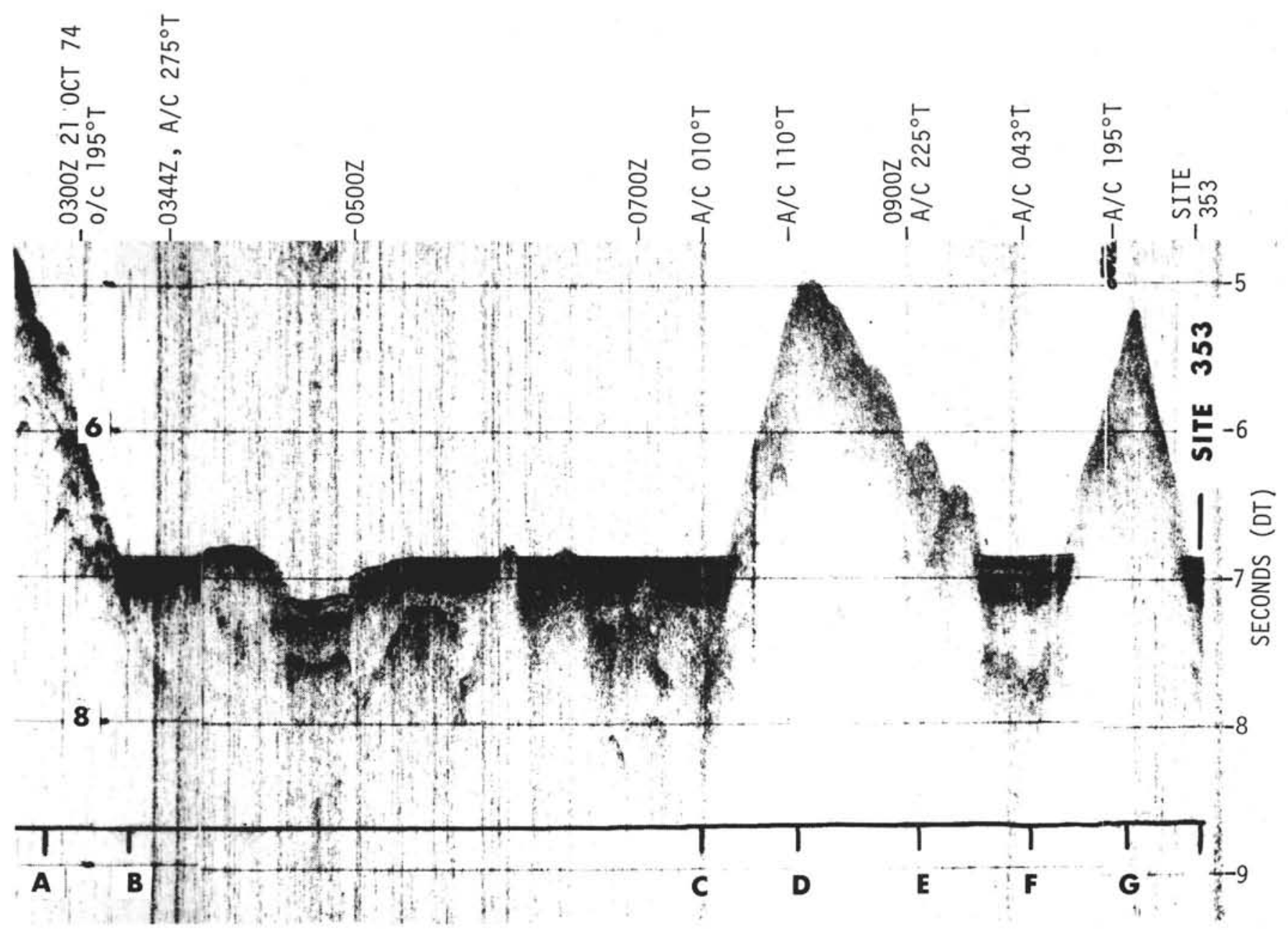

Figure 6. Glomar Challenger seismic reflection profile on approach to Site 353.

TABLE 1

Coring Summary, Site 353

\begin{tabular}{|c|c|c|c|c|}
\hline Core & $\begin{array}{l}\text { Depth Below } \\
\text { Sea Floor } \\
(\mathrm{m})\end{array}$ & $\begin{array}{l}\text { Length } \\
\text { Cored } \\
\text { (m) }\end{array}$ & $\begin{array}{l}\text { Length } \\
\text { Recovered } \\
\text { (m) }\end{array}$ & $\begin{array}{c}\text { Recovery } \\
(\%)\end{array}$ \\
\hline \multicolumn{5}{|c|}{ Hole 353} \\
\hline $\begin{array}{l}1 \\
2 \\
3\end{array}$ & $\begin{array}{c}0.0-4.5 \\
118.5-128.0 \\
261.0-270.5\end{array}$ & $\begin{array}{l}4.5 \\
9.5 \\
9.5\end{array}$ & $\begin{array}{l}1 \mathrm{~cm} \\
3.6 \\
1.8\end{array}$ & $\begin{array}{l}\mathrm{Tr} \\
38 \\
19\end{array}$ \\
\hline Total & & 23.5 & $5.4+$ & 23 \\
\hline \multicolumn{5}{|c|}{ Hole 353A } \\
\hline 1 & $0.0-181.0^{\mathrm{a}}$ & & 3.1 & \\
\hline \multicolumn{5}{|c|}{ Hole 353B } \\
\hline 1 & $168.0-181.0$ & & 1.1 & \\
\hline
\end{tabular}

again very stiff while the last 2 meters of Core 3 were cut, and the core contained only a $1.5-\mathrm{cm}$ sand layer. We continued washing to a depth of 384.5 meters, where, at $0030 \mathrm{Z}, 23$ October 1974, the Bowen sub- assembly failed. Fortunately, a spare unit was aboard, but replacement would take approximately 12 hours. The drill pipe had to be out of the hole to a distance of 245 meters above the mud line and replacement work began.

While we were still on Hole 353 , we released a sonobuoy to drift away from the ship. This record is shown and discussed in the section on correlation of geophysics with drilling results.

Since the sediment at the original drill location was thicker than expected and needed, we performed geometric calculations to aid in considering the advisability of an offset to the north. Re-examination of the PDR record showed the actual angle of the north wall along the site approach line to be about $30^{\circ}$. If this angle stays constant beneath the sediment fill, and the calculation of $0.75 \mathrm{~km}$ from the foot of the wall was correct, then there should be some 370 meters of sediment (almost exactly what was drilled before the Bowen sub failed) at the first site. Assuming this to be so, we calculated that it was necessary to relocate some 450 meters farther north to find a sediment thickness of about 150 meters.

While repairs were being made on the rig floor, we steamed on a northerly offset at a speed of about 0.25 knots without pulling the drill pipe. A total offset of 
1000 meters was achieved without depth change on the PDR; this indicated our original calculation of relative site location to be in error. A vertical profile record recorded by a tethered sonobuoy toward the end of the offset steam, and continued while at Hole 353A, showed a reflector presumed to be basement at 0.3 at the offset position (see correlation section).

A $13.5-\mathrm{kHz}$ beacon was dropped at $1451 \mathrm{Z}, 23$ October, pipe was run, the heave compensator and new Bowen sub were picked up, and Hole 353A was spudded at $1800 \mathrm{Z}, 23$ October. Washing was routine and fast $(135 \mathrm{~m} / \mathrm{hr})$ to a subbottom depth of 168 meters, where tight hole was encountered. Over four hours of attempt yielded only 13 meters of penetration. Extreme torquing and difficulty in moving the pipe up and down indicated we were not going to make hole in this material and that we stood a good chance of getting stuck in it, so we abandoned the hole. We presumed that we had hit a breccia or talus deposit, and decided to pull above the mud line and offset the vessel up-dip 100 meters and along strike 200 meters, in an attempt to get around the deposit. The mud line was cleared at $0120 \mathrm{Z}, 24$ October. The core barrel was pulled at this time, during a one hour period of ship's repair downtime. The core was on deck at $0245 Z$; it contained six basalt cobbles overlain by 3 meters of mud and sand. The rounded cobbles confirmed our surmise of a talus deposit.

The offset to Hole 353B was completed by $0320 \mathrm{Z}, 24$ October, and the hole was spudded at 0415Z. Drilling results here were identical to those at Hole 353A: washing was routine to 168 meters subbottom, where torquing again began. We attempted for three hours to penetrate, with only marginal results; further penetration, if possible at all, would very probably have caused us to get stuck, so we again had to abandon the hole.

Encountering the same conditions after a 225-meter offset indicated that the rubble zone was of regional extent. Because of time constraints, we decided not to attempt a further offset, and at 1145Z, 24 October, decided to pull pipe preparatory to departure for Site 354.

At $0003 \mathrm{Z}, 25$ October, we steamed north from Hole 353B, deployed gear, executed a turn to starboard, and returned on a southerly course to cross the beacons at Holes $353 \mathrm{~A}$ and 353 . At $0053 \mathrm{Z}$, we crossed the foot of the north wall and took a range on the $353 \mathrm{~A}$ beacon. We learned that Holes 353, 353A, and 353B were 1200 , 300 , and 200 meters from the wall, respectively.

At $0058 \mathrm{Z}$, we were over the Hole 353 beacon and altered course to $260^{\circ}$ to approximate the course of the sonobuoy released at Hole 353. At $0133 \mathrm{Z}$, we increased speed to 10 knots. At $0245 \mathrm{Z}$ we changed course to $205^{\circ} \mathrm{T}$, crossed the steep south wall of the Vema Fracture Zone, and set our course directly toward Site 354 .

\section{LITHOLOGY}

\section{Sediments}

Sediment recovery was not a priority at Site 353 . We took cores containing sediment from Holes 353 and $353 \mathrm{~A}$; the core recovered at Hole 353B only sampled basalt fragments. In Hole 353, we obtained three cores through a 385-meter interval; the one core from Hole $353 \mathrm{~A}$ contains only a sample 3.1 meters long, retrieved after drilling continuously for 181 meters. No definition of lithologic units or extended discussion of sedimentology is warranted. Stratigraphic relationships are difficult to determine.

In general, we cored a wide variety of sediment types and textures, from sands to muds to foraminifernannofossil oozes. Colors are predominantly dark brown and gray. Bioturbated structures occur only in one $50-\mathrm{cm}$ portion (Sample 353-2-2, 40-90 cm); otherwise, visible sedimentary structures are predominantly graded beds up to 1 meter thick (Core 353-3), or distinct sand and silt laminae without apparent grading but with sharp upper and lower contacts. Some fissile structures are present (Core 353A-1), but probably result from the repeated coring, compression, and washing of material in this core.

The entire section recovered is of Pleistocene age, and upper Pleistocene material is the oldest recovered. Sedimentary structures, textures, and composition indicate that these sediments are displaced material deposited by turbidity currents originating at the continental borderland, and perhaps by slumping from the nearby north wall of the Vema Fracture Zone escarpment. Because coring was intermittent, subunits within turbidite sequences cannot be distinguished.

Compositionally, the sediment is a mixture of both terrigenous and pelagic components; the latter also contains a significant proportion of displaced material (see biostratigraphy section). Sand- and silt-sized terrigenous grains are predominantly quartz, with feldspar, micas, heavy minerals, and clays, an assemblage very similar to those from Holes 26 and 26A, DSDP Leg 4 (Bader, Gerard, et al., 1970). The section recovered during Leg 39 drilling, however, apparently has a higher biogenic component of calcareous foraminifers, nannofossils, and fine-grained micarb, as well as sponge spicules and some diatom remains. Small silt-sized subangular to subrounded, slightly greenish grains of anhedral carbonate are ubiquitous, and generally form about $5 \%$ to $10 \%$ of a sample, but locally may reach $40 \%$ (Sample 353-1-2, 31$37 \mathrm{~cm}$ ). These appear similar to anhedral calcite grains, from western Pacific sediments, whose origin has been ascribed to hydrothermal alteration of calcareous oozes (Pimm et al., 1971), and may be equivalent to the angular calcite noted from Hole 26 (Bader, Gerard, et al., 1970).

Detrital minerals occur in wide variety in the sand and coarse-silt sizes. Quartz forms up to $30 \%$ of this fraction (Sections 353-3-1 and 353-3-2) and as much as $58 \%$ of the very fine sand portion (Sample 353A-1, CC; see Emelyanov and Trimonis, this volume). Quartz occurs as clear grains or as grains containing either hematite veinlets or rutile inclusions; no frosted grains are apparent. Feldspars and micas are common. Feldspar content averages $5 \%$ to $15 \%$ in smear slide, and is apparently concentrated in the finer size fraction (up to 47\%; see Emelyanov and Trimonis, this volume). Micas are predominantly muscovite, but a high proportion of biotite also occurs in the finer sizes (see Emelyanov and Trimonis, this volume). Glauconite 
and chlorite are common. Heavy minerals are significant and varied. In smear slides, they comprise up to $20 \%$ of the total sediment (Sample 353-3-1, 142 $\mathrm{cm})$; more often, however, their abundance is, we estimate, about $5 \%$. They are mainly green and brown hornblende, pyroxene (often with serrated edges), tourmaline, zircon, opaque minerals, and corundum (?). Laboratory studies (see Emelyanov and Trimonis, this volume) suggest an even more varied suite within the finer grain sizes, where they make up between $2 \%$ and $14 \%$ of the fraction. There is a predominance of unstable varieties (hornblende, pyroxene, actinolitetremolite, epidote, olivine) in comparison with the more stable types (magnetite, ilmenite, garnet, zircon, apatite, rutile, muscovite, tourmaline, staurolite, kyanite). Plant debris is present but not abundant. Minor amounts of lithic fragments (schist?) occur. In Sample 353-3-2, $145 \mathrm{~cm}$, larger rock fragments up to 2.5 by $1.5 \mathrm{~cm}$ are present; in thin section, they are composed of long (up to $100 \mu \mathrm{m}$ ) radiating aragonite needles with iron and manganese oxides and quartz interspersed between the needles. Zeolites occur in trace quantities, especially in sediments from Hole 353A.

The entire assemblage of detrital minerals suggests derivation from Amazon River material. Most distinctive is the heavy mineral suite with a high proportion of unstable varieties (compare, for example, with Gibbs, 1967; Milliman et al., 1975; Damuth and Kumar, 1975). High quartz and feldspar quantities are also characteristic of an Amazon provenance (Gibbs, 1967; McGeary, 1969; Damuth and Fairbridge, 1970; Damuth and Kumar, 1975)-in particular, quartz grains containing hematite veins or rutile inclusions (see also Bader, Gerard, et al., 1970). The quartz may be derived from the quartz-rich sediments on the continental shelf off and south of the Amazon River; feldspars represent modern Amazon River material on the Amazon Cone (Milliman et al., 1975). Micas, particularly muscovite, are also distinctive (see Gibbs, 1967). In general, the overall concentrations of heavy minerals, quartz, micas, and feldspars are very similar to those in sediments elsewhere in the Vema Fracture Zone (see McGeary, 1969; Bader, Gerard, et al., 1970). Glauconite may represent the alteration of organic detritus within turbidite sequences.

Calcareous components also suggest reworking (see biostratigraphy section). They may have been introduced with the detrital material by turbidity currents; the zeolites have most likely been similarly transported into the Vema Fracture Zone. Reworking by bottom currents could also account for the relatively higher proportion of calcareous components; McGeary (1969) has noted other evidence for bottom current activity within the fracture zone.

There is an indication of local sediment contribution from the fracture zone escarpment. Olivine is present in the heavy mineral fraction of one sample, and up to $9 \%$ of this suite may be derived from local volcanic areas (see Emelyanov and Trimonis, this volume). Hydrothermal alteration is indicated by the anhedral carbonate particles and by the rock fragments containing aragonite needles.
Basalts

\section{Hole 353A}

A number of basalt fragments were recovered at the bottom of the core barrel and above the core catcher. There are six larger fragments, measuring roughly 5-10 $\mathrm{cm}$ in diameter. Several smaller fragments are also present. Some of the cobbles appear to have been partially rounded by the action of the drill, and must have originally been parts of larger cobbles.

Microscopic examination of thin sections of three of the larger fragments indicates the following features.

Sample 1-2, Piece \#5: Aphyric olivine basalt. Feathery texture with clusters of elongated plates and needles of calcic plagioclase, clustered on preferred orientations. Frequent skeletal platelets of plagioclase, resulting from rapid chilling. Abundant isolated, partly euhedral crystals of olivine, partly altered to a smectitechlorite mixture. Very fine intersertal groundmass, containing secondary phases, opaque minerals, and probably some glass.

Sample 1, CC: Aphyric olivine basalt. This basalt is very similar to Piece \#5, described above, except for smaller crystal size and overall poorer crystallinity. Clusters of calcic plagioclase needles plus isolated olivine crystals, partly euhedral, in a very fine groundmass dusted with opaque minerals. Skeletal olivine crystals observed.

Sample 1-2, Piece \#1: Same as Sample 1, CC above. Among the smaller fragments, one consisting of fresh basaltic glass was used for fission track dating.

\section{Hole 353B}

The core collected at the base of this hole (168-181 m beneath the sea floor) contains 19 fragments of basalt, ranging in diameter from 5 to $15 \mathrm{~cm}$. Some of the fragments appear to have been smoothed on one side by the drill bit; this suggests that they were originally part of larger fragments.

Thin sections of some of the larger fragments show the following features.

Sample 1-1, Piece \#14: Sparsely phyric olivine basalt. Microphenocrysts of euhedral olivine and clusters of fine calcic plagioclase needles, scattered in a fine glassy groundmass containing smectitic alteration products and dusted with opaque minerals. A few vesicles are present. One very large euhedral phenocryst of olivine occurs. It is relatively fresh except for some alteration along cleavage planes.

Sample 1-1, Piece \#1: Skeletal elongated plates of calcic plagioclase and micropheyocrysts of relatively fresh olivine, in a groundmass of fine secondary phases, opaque minerals, and probably some glass.

Sample 1-2, Piece \#3: Glassy olivine basalt. Scattered euhedral crystals of olivine in a glassy groundmass, with thin needles of plagioclase and alteration products of glass (smectites).

Sample 1-2, Piece \#16: Same as Piece \#3 above.

The mineralogy of these basalts appears to be characteristic of olivine tholeiites, the common rock type obtained from oceanic spreading centers. The 
relative freshness of these basalts suggests that they are very young. Hence, they probably represent material emplaced at the northern axial segment of the MidAtlantic Ridge and subsequently transported laterally by the spreading process.

\section{FISSION TRACK AGE OF GLASS (D.E.F.)}

An attempt was made to date glass by the fission track technique (Fleischer and Price, 1964). The U content was determined to be only $6 \mathrm{ppb}$, instead of the 75-300 ppb anticipated (Fisher, 1975). This low U content leads to an extremely low fossil track density (Table 2). In fact, only four fossil tracks were counted in over 2000 fields of view, at a magnification of $\times 500$, representing one man-week of track scanning. The density of bubbles, holes, scratches, etc., in the glass is much greater than this, and the presence of such features may resemble a track sufficiently to be mistaken for one. In samples with high track densities, the error caused by an occasional such misidentification is negligible; at the extremely low density encountered here, it is not. The possibility that any of the tracks might in fact have been such a feature cannot be discounted, so the age is reported in Table 2 only as an upper limit. To reduce the error to approximately $\pm 0.5 \mathrm{~m}$.y. on the basis of statistics alone would require several man-months of track scanning. Even then, the error resulting from possible incorrect track identification would be difficult to evaluate.

The U content was determined by counting neutroninduced tracks on an interior surface, and has a large uncertainty $( \pm 50 \%)$ (Fisher, 1975). In view of the lack of positive results for the age determination, a more precise determination of the $U$ content was not attempted.

TABLE 2

Fission Track Analysis of Glass from Site 353

\begin{tabular}{ccccc}
\hline $\begin{array}{c}\text { Density of } \\
\text { Fossil Tracks } \\
\left(\mathrm{cm}^{-2}\right)\end{array}$ & $\begin{array}{c}\text { Density of } \\
\text { Induced } \\
\text { Tracks } \\
\left(\mathrm{cm}^{-2}\right)\end{array}$ & $\begin{array}{c}\text { Flux } \\
\left(\mathrm{n} / \mathrm{cm}^{2}\right)\end{array}$ & $\begin{array}{c}\text { U Content } \\
(\mathrm{ppb})\end{array}$ & $\begin{array}{c}\text { Age } \\
\left(\times 10^{6} \mathrm{yr}\right)\end{array}$ \\
\hline 4.1 & $1.7 \times 10^{4}$ & $2.3 \times 10^{17}$ & 6 & 5 \\
\hline
\end{tabular}

\section{GEOCHEMISTRY}

Two interstitial water samples were analyzed onboard ship. Data are in Table 3.

\section{PHYSICAL PROPERTIES}

Because the objectives of drilling at Site 353 dictated a minimum of sediment recovery, only about three meters of undisturbed core were useful for measure- ment of physical properties, and few determinations were made (Table 4).

\section{BIOSTRATIGRAPHIC SUMMARY}

The planktonic foraminifers studied from Holes 353 and 353A are of Pleistocene age (Globorotalia truncatulinoides Zone) and show signs of intensive solution, as could be expected from their deposition and/or redeposition close to the CCD. Extensive redeposition of faunas is indicated by the presence of Pliocene forms and the size-sorting of planktonic faunas. The preservation at a depth of over 5000 meters of aragonitic fossils such as the pteropod Creseis sp. and the aragonitic benthic foraminifer Hoeglundina elegans ((d'Orbigny), and the presence of benthic foraminifers, presumably derived from shelf environments, also indicate redeposition.

Calcareous nannofossils indicate a late Pleistocene age (Emiliania huxleyi and Gephyrocapsa oceanica zones) for all samples studied, except the lowermost sample (353-3, CC), at a depth of 367 meters, which might belong to the lower Pleistocene Pseudoemiliania lacunosa Zone. Reworked floras are common in some samples, and include upper Oligocene to lower Pleistocene forms. Only fragments of radiolarians and diatom remains were found.

\section{Foraminifers}

Both planktonic and benthic foraminifers were studied from the four cores from Holes 353 and 353A. Stephen Streeter analyzed the benthic specimens. The core samples are generally similar in their degree of solution, fragmentation, impoverished faunas, and in the presence of redeposited materials. All samples contain Globorotalia truncatulinoides, and are thus assigned to the Pleistocene $G$. truncatulinoides Zone. The presence of $G$. flexuosa in Core 353A-1, the core that most likely represents in situ deposition and solution, suggests an age of more than 8000 m.y.B.P. for these sediments, according to the time scale and zonation of Berggren (1972).

The planktonic foraminifers in the cores from Holes 353 and $353 \mathrm{~A}$ are similar and represent a more or less dissolved tropical fauna. Faunas differ primarily in the degree of solution, fragmentation, the amount and types of nonbiogenic materials, and the types of redeposited fossils. These and other characteristics of the samples are summarized in Table 5.

Because of the turbidite origin of most of these samples, the history of solution at this site is confused. Solution-resistant species remain whole in some samples, whereas other samples contain impoverished faunas of species both more and less resistant. Sizesorting, stratigraphic reworking, and downslope

TABLE 3

Summary of Shipboard Geochemical Data

\begin{tabular}{cccccccc}
\hline Sample & $\begin{array}{c}\text { Sample } \\
(\text { Interval in cm) }\end{array}$ & $\begin{array}{c}\text { Subdepth } \\
(\mathrm{m})\end{array}$ & $p \mathrm{H}$ & $\begin{array}{c}\text { Alkalinity } \\
(\mathrm{meq} / \mathrm{l})\end{array}$ & $\begin{array}{c}\text { Salinity } \\
(\%)\end{array}$ & $\begin{array}{c}\mathrm{Ca}++ \\
(\mathrm{mmoles} / \mathrm{l})\end{array}$ & $\begin{array}{c}\mathrm{Mg}++ \\
(\mathrm{mmoles} / \mathrm{l})\end{array}$ \\
\hline 1 & $2-2,144-150$ & 121.5 & 7.47 & 7.43 & 32.2 & 5.82 & 39.34 \\
2 & $3-1,144-150$ & 262.5 & 8.06 & 2.17 & 36.6 & 9.66 & 53.41 \\
\hline
\end{tabular}


TABLE 4

Physical Properties, Site 353

\begin{tabular}{|c|c|c|c|c|c|c|c|c|c|c|c|c|}
\hline \multirow{2}{*}{$\begin{array}{c}\text { Sample } \\
\text { (Interval in } \mathrm{cm} \text { ) }\end{array}$} & \multirow{2}{*}{$\begin{array}{l}\text { Depth } \\
(\mathrm{m})\end{array}$} & \multirow{2}{*}{$\begin{array}{l}\text { Velocity } \\
(\mathrm{km} / \mathrm{sec})\end{array}$} & \multicolumn{3}{|c|}{ Density $(\mathrm{g} / \mathrm{cc})$} & \multirow{2}{*}{$\begin{array}{l}\text { Water } \\
\text { (wt \%) }\end{array}$} & \multicolumn{3}{|c|}{ Porosity (\%) } & \multicolumn{3}{|c|}{$\begin{array}{l}\text { Acoustic } \\
\text { Impedance }\end{array}$} \\
\hline & & & S & I & G & & S & I & G & S & I & G \\
\hline $2-2,120$ & 121.20 & - & 1.785 & - & - & - & 54.63 & - & - & - & - & - \\
\hline $2-2,123$ & 121.23 & - & 1.794 & - & - & - & 54.09 & - & - & 2.86 & - & - \\
\hline $2-2,130$ & 121.30 & 1.593 & - & - & - & - & - & - & - & - & - & - \\
\hline $2-3,30$ & 121.80 & 1.604 & - & - & - & - & - & - & - & - & - & - \\
\hline $2-3,112$ & 122.62 & 1.563 & - & - & - & - & - & - & - & 2.86 & - & - \\
\hline $2-3,115$ & 122.65 & - & 1.829 & - & - & - & - & - & - & - & - & - \\
\hline $2-3,115$ & 122.65 & - & 1.857 & - & - & - & 40.33 & - & - & 2.93 & - & - \\
\hline $2-3,130$ & 122.80 & 1.580 & - & - & - & - & - & - & - & - & - & - \\
\hline $3-1,-0$ & 261.00 & - & 1.860 & - & - & - & 50.15 & - & - & - & - & - \\
\hline $3-2,36$ & 262.86 & 1.778 & - & - & - & - & - & - & - & 3.56 & - & - \\
\hline $3-2,40$ & 262.90 & - & 2.000 & - & - & - & 41.79 & - & - & - & - & - \\
\hline $3-2,77$ & 263.27 & 1.770 & - & - & - & _- & - & - & - & 3.69 & - & - \\
\hline $3-2,80$ & $263.3 \theta$ & - & 2.085 & - & - & - & 36.72 & - & - & - & - & - \\
\hline $3-2,117$ & 263.67 & 1.760 & - & - & - & - & - & - & - & 3.32 & - & - \\
\hline $3-2,120$ & 263.70 & - & 1.886 & - & - & - & 48.60 & - & - & - & - & - \\
\hline
\end{tabular}

Note: $S=$ syringe technique, $I=$ immersion technique, $G=$ GRAPE.

TABLE 5

Sample Componen ts, Site 353

\begin{tabular}{|c|c|c|c|c|c|}
\hline $\begin{array}{l}\text { Hole/ } \\
\text { Core }\end{array}$ & $\begin{array}{l}\text { Planktonic } \\
\text { Foraminifers }\end{array}$ & $\begin{array}{l}\text { Benthonic } \\
\text { Foraminifers }^{\mathrm{a}}\end{array}$ & $\begin{array}{l}\text { Nonbiogenic } \\
\text { Components }\end{array}$ & Other Fossils & $\begin{array}{l}\text { \% Loss from } \\
\text { Solution }{ }^{b}\end{array}$ \\
\hline $353-2$ & $\begin{array}{l}\text { G. truncatulinoides } \\
\text { G. menardii } \\
\text { G. tumida } \\
\text { G. flexuosa } \\
\text { G. ruber (pink) } \\
\text { G. conglobatus } \\
\text { G. dutertrei } \\
\text { G. pachyderma (right) }\end{array}$ & $\begin{array}{l}\text { Mixed shelf to } \\
5000 \mathrm{~m} \text { depth } \\
\text { faunas-miliolids } \\
\text { from less than } \\
80 \text { meters }\end{array}$ & $\begin{array}{l}\text { More than } 90 \% \\
\text { quartz, feldspar, } \\
\text { metamorphic } \\
\text { rock fragments, } \\
\text { and mica }\end{array}$ & Plant debris & $>90 \%$ \\
\hline $353-3$ & $\begin{array}{l}\text { All the above, plus: } \\
\text { G. inflata } \\
\text { G. crassaformis } \\
\text { G. sacculifer } \\
\text { S. dehiscens } \\
\text { P. obliquiloculata } \\
\text { Reworked Pliocene } \\
\quad \text { Fossils }\end{array}$ & $\begin{array}{l}\text { Mixed shelf to } \\
5000 \text { meter } \\
\text { faunas; arago- } \\
\text { nitic form, } \\
\text { Hoeglundina } \\
\text { elegans present }\end{array}$ & $\begin{array}{l}\text { Rock fragments, } \\
\text { feldspars, quartz }\end{array}$ & $\begin{array}{l}\text { Smooth and } \\
\text { ribbed ostracodes; } \\
\text { pteropod genus } \\
\text { Cresius; echinoid } \\
\text { spines }\end{array}$ & $\begin{array}{l}0 \text { to } \\
80 \%-90 \%\end{array}$ \\
\hline $353 \mathrm{~A}-1$ & $\begin{array}{l}\text { G. truncatulinoides } \\
\text { S. dehiscens } \\
\text { G. menardii } \\
\text { G. ruber }\end{array}$ & $\begin{array}{l}\text { Fauna appears } \\
\text { in place }\end{array}$ & $\begin{array}{l}\text { Rock fragments, } \\
\text { feldspars }\end{array}$ & $\begin{array}{l}\text { Fish teeth, } \\
\text { echinoid spines }\end{array}$ & $>95 \%$ \\
\hline
\end{tabular}

\footnotetext{
${ }^{\mathrm{a}}$ Benthic foraminifers were analyzed by Stephen Streeter (personal communication, 1975).

${ }^{b}$ Percent loss from solution is computed from the scheme of Berger (1972). In this instance the situation on the bottom at this site is probably reflected in the samples from Hole 353A, while turbidity redeposition has masked the solution potential at the site in the samples from Hole 353. Thus Core 353-3 gives solution values of both 0 and $80 \%-90 \%$ in one sample.
}

redeposition also characterize the sediments from these holes.

In summary, the foraminifers from Holes 353 and $353 \mathrm{~A}$ are of Pleistocene age. Most of these samples, which were redeposited and/or redeposited close to the CCD, have been intensely dissolved. Core 353A-1 probably typifies undisturbed sediments from this depth and location, and hence in situ solution rather than redeposition. Redeposition in other samples from this site is indicated by: (1) aragonitic fossils; (2) Pliocene foraminifers; (3) mixed lithologies; (4) shelf- depth foraminifers; and (5) the size-sorting of the foraminifers.

\section{Calcareous Nannofossils}

No sediments were recovered in Core 353-1, (0.0-4.5 $\mathrm{m})$; but a smear slide, prepared from the mud attached to the core liner, contains rare and moderately well preserved coccoliths, including Emiliania huxleyi, Gephyrocapsa oceanica, and Ceratolithus cristatus, which suggest that this mud is upper Pleistocene to Holocene (NN 21). The assemblage includes only 
solution-resistant forms; this indicates deposition near CCD. Only few reworked forms are present. All three samples from Core 2, which contains turbidite clays and sands, include rich tropical assemblages in which some more delicate species are still preserved; this suggests that they probably reached this depth with a turbidity current and were rapidly buried. Sample 3532, CC includes common $G$. oceanica, but no Pseudoemiliania lacunosa, and thus belongs to the upper Pleistocene G. oceanica Zone (NN 20). The two samples of a gray clay and a cream-colored layer in Sample 3532-2, $54 \mathrm{~cm}$ include $P$. lacunosa, together with other reworked coccoliths and discoasters. The age ranges represented by the reworked forms in the two lithologies differ slightly. The gray clay, which constitutes the bulk of the recovered sediment, contains mainly lower Miocene to middle Miocene and upper Pliocene to lower Pleistocene fossils, not including Reticulofenestra pseudoumbilica. The presence of the latter species indicates reworked upper Miocene or lower Pliocene material in the cream-colored sediment, which contains more reworked calcareous nannofossils than any other sample studied from this hole.

Two samples were studied from Core 353-3. The outwash from the sandy turbidite in Sample 353-3-2, 50 $\mathrm{cm}$ contains an assemblage of the $G$. oceanica Zone, only a minor amount of reworked Neogene coccoliths, and no $P$. lacunosa. $P$. lacunosa is very rare in the otherwise similar assemblage in Sample 353-2, CC, which contains more reworked forms. It is thus possible that, despite the sparse presence of $P$. lacunosa, this deepest sample in Hole 353 still belongs to the $G$. oceanica Zone.

The core barrel retrieved from the bottom $(181 \mathrm{~m})$ of Hole $353 \mathrm{~A}$ when it was abandoned had also been in place for the previous drilling at Hole 353. Although we cannot be certain, it is likely that the sediment cored came from the bottom of Hole 353A. The coccolith assemblage in Sample 353A-1-2, $40 \mathrm{~cm}$, consists of almost the same species as the samples from Hole 353, and belongs to the G. oceanica Zone. Here, however, small Prinsiaceae dominate the assemblage completely, and Pleistocene ceratoliths, present in reasonable numbers in the other samples, are missing. This suggests a cooler environment during the deposition of this assemblage, which contains only few reworked Neogene species. If the dominance of small Prinsiaceae were a result of solution of the delicate species rather than cooler climate, ceratoliths should be present and the preservation of the delicate species should be poorer than it is.

In Hole 353B, the core barrel again stayed in the pipe for the entire depth of the hole and was retrieved together with the pipe when we left the hole. The core contains only pieces of basalt. Sediment scratched from one piece (Sample 353B-1-1, $25 \mathrm{~cm}$ ) yielded only a very few fairly well preserved coccoliths of the upper Oligocene to the Miocene and Pleistocene (Helicopontosphaera intermedia, Discoaster deflandrei, and small Prinsiaceae, possibly Gephyrocapsa sp.).

Sediments in the Vema Fracture Zone were cored to a depth of 483 meters at Site 26, DSDP Leg 4. Hay (1970) reports sparse to poor assemblages of cal- careous nannofossils throughout the recovered sediments, and a few barren samples. He also suggests that the boundary between the $G$. oceanica and P. lacunosa zones lies between 238.5 meters and 408 meters, in accordance with our findings. The 23 coccolith samples tabulated by Hay (1970) show much less diverse Pleistocene assemblages than those found at Site 353, and consistently fewer and less diverse reworked coccoliths.

\section{SEDIMENT ACCUMULATION RATES}

Figure 7 summarizes the results of drilling at Site 353 near the northern wall of the Vema Fracture Zone. Core 1 belongs to the E. huxleyi Zone $(0$ to $0.2 \mathrm{~m}$.y. ago). Most of the sequence seems to fall within the $G$. oceanica Zone, to which an age of from 0.2 to $0.4 \mathrm{~m} . \mathrm{y}$. has been assigned (Gartner, 1973). Sample 353-3-2, 50 $\mathrm{cm}$, is still in the $G$. oceanica Zone, and the core-catcher sample of Core 3 may belong to the P. lacunosa Zone. Assuming an age of 0.4 m.y. in 353-3, CC (depth of 270 $\mathrm{m})$, the average accumulation rate seems to have been about $70 \mathrm{~cm} / 1000 \mathrm{yr}$ (not corrected for compaction, etc.).

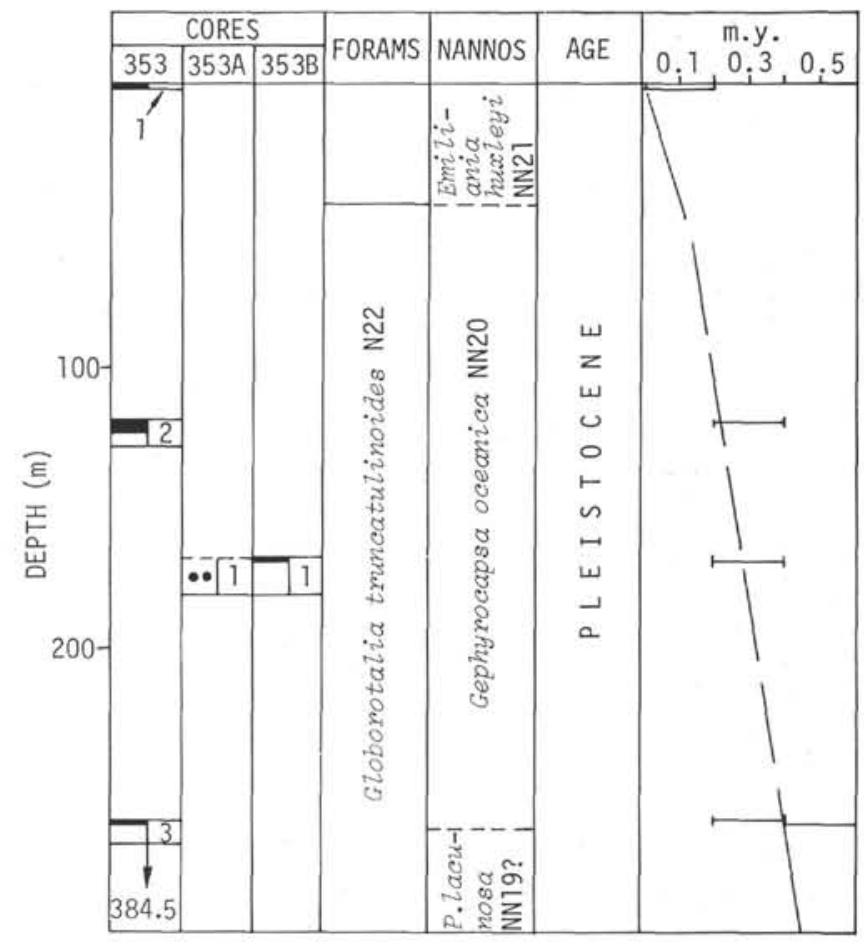

Figure 7. Biostratigraphic column and sedimentation at Site 353.

\section{CORRELATION OF REFLECTION PROFILE WITH DRILLING RESULTS}

\section{Seismic Profiling and Sonobuoy Measurement}

To locate Site 353 at a point near the northern wall of the Vema Fracture Zone where the sedimentary section was of the minimum thickness required, we had to make several crossings before we dropped the beacon. 
Glomar Challenger track approach and position of Site 353 are shown in Figure 5.

Because of the steep basement slope near the northern wall, side echoes introduce difficulties in interpretation of the records. The true angle of the bottom slope on these records was determined by comparison with echo sounding records.

The Glomar Challenger airgun reflection profiles obtained in the Vema trench area have the same major characteristics as the van Andel et al. (1971) profiles.

The first crossing of the northern slope and adjoining flat bottom of the valley was made in the central part of the trench, east of the north spreading axis. The seismic reflection profile shows a very steep basement slope and sharply increasing sediment thickness (Figure 4).

The seismic profile along the foot of the slope shows a very rough basement at a depth below bottom greater than 1 sec DT (Figure 6), although basement highs appear at two places on the profile. Another feature of this profile is what appears to be a large graben offsetting the bottom and the basement. It is about 200 meters deep and $5 \mathrm{~km}$ wide, and is on the extension of the central rift valley of the Mid-Atlantic Ridge. One may conclude from the structure that this graben is rather young: only about $0.1 \mathrm{sec}$ DT of sediments cover the first strong reflector.

The second, third, and fourth crossings of the northern slope were made west of the northern rift valley, before we dropped the beacon at Site 353. All these profiles show a very steep basement slope (about $30^{\circ}$ ) (Figure 6).

We attempted to drop the beacon at a point where the sediment thickness was $200-300$ meters, but the thickness increased very sharply. The drilling results and seismic sonobuoy record made at Site 353 disclose a sediment thickness of about 600 meters.

The sonobuoy record obtained at Site 353 is shown in Figure 8 . The sonobuoy drifted with the current to the west (on course about $260^{\circ}$ ) from the drilling point. The length of the profile was about $3.7 \mathrm{~km}$. Because the profile was short, refracted arrivals were not received. Calculation of velocity from the reflection waves received on this profile is difficult, owing to great variations of the depths of lower reflectors along the profile.

Vertical times and depths of the main reflectors are given in Table 6 . The depth was calculated by assuming an average velocity of $1600 \mathrm{~m} / \mathrm{sec}$, according to data from Leg 4, Site 26 (Bader, Gerard, et al., 1970) and sonic velocity measurements on samples collected at Site 353 . The sonobuoy profile shows two disconformities in the sediment section: the first at a depth about 200 meters below the sea floor and the second at a depth of about 500 meters (Figures 8 and 9). The uppermost four beds are almost horizontal. The depths of the lower reflecting horizons change along the profile.

After drilling Hole 353, Glomar Challenger steamed slowly north to an offset hole nearer the foot of the slope. Vertical reflection measurements were conducted using an airgun of 30 in. $^{3}$ and a tethered sonobuoy. Results of the depth calculations for the main reflectors are given in Table 7. The seismic records (Figure 10) show that the sediment section is divided into two
TABLE 6

Seismic Reflection Data, Hole 353

\begin{tabular}{rll}
\hline Reflector & DT $(\mathrm{sec})$ & $\begin{array}{c}\text { Depth From } \\
\text { Sea Floor }(\mathrm{m}) \\
(V=1.6 \mathrm{~km} / \mathrm{sec})\end{array}$ \\
\hline 1 & 0.04 & 32 \\
2 & 0.08 & 64 \\
3 & 0.14 & 112 \\
4 & 0.23 & 184 \\
5 & 0.30 & 240 \\
6 & 0.38 & 304 \\
7 & 0.41 & 328 \\
8 & 0.72 & 576 \\
9 & 0.82 & 656 Basement $(?)$ \\
10 & 0.93 & $(?)$ \\
11 & 1.08 & $(?)$ \\
\hline
\end{tabular}

TABLE 7

Seismic Reflection Data, Hole 353A

\begin{tabular}{ccrcc}
\hline & & \multicolumn{1}{c}{$\begin{array}{c}\text { Depth From } \\
\text { Sea Floor }(\mathrm{m}) \\
(V=1.6 \mathrm{~km} / \mathrm{sec})\end{array}$} \\
\hline Reflector & DT (sec) & \multicolumn{3}{c}{} \\
1 & 0.04 & 32 & & \\
2 & 0.08 & 64 & & \\
3 & 0.12 & 96 & & \\
4 & 0.21 & $168=3.0 \quad V=4.0$ Basalt breccia \\
5 & 0.28 & 224 & $273 \quad 308$ \\
\hline
\end{tabular}

parts: an upper well-stratified layer and a basal acoustically transparent layer (below reflector 4). The features of sediment structure are the same here as in another seismic reflection profile near the foot of the northern slope of the Vema trench (see Figure 6).

\section{Comparison of the Seismic and Drilling Data}

The drilling results and the seismic reflection data are compared in Figure 11 and Tables 6 and 7.

The uppermost 200 meters of the seismic section at Hole 353 and 100-150 meters at Hole 353A appear to consist of silt and silty clays interbedded with sands. Because of insufficient core control, we could not determine the nature of reflectors $1-4$ at Hole 353 and reflectors $1-2$ at Hole $353 \mathrm{~A}$.

Reflector 5 at Hole 353 may correspond to the depth at which a thick sand bed (about one meter) was recovered. Shipboard measurements gave sonic velocities of about $1800 \mathrm{~m} / \mathrm{sec}$ and density of about 2.0 $\mathrm{g} / \mathrm{cc}$ for this sand, as opposed to $1600 \mathrm{~m} / \mathrm{sec}$ and 2.8 $\mathrm{g} / \mathrm{cc}$ for the clays. The significant difference in the acoustic impedance for these sands and clays (3600 and 2880 , respectively) must generate seismic reflections at the boundary of these beds. Thus reflector 5 and probably reflectors 6 and 7 at Hole 353 may correspond to beds of sand.

Unfortunately, we did not penetrate the basement (reflector 9 at Hole 353 and reflector 5 at Hole 353A), and its nature is unknown.

At Hole 353A, we penetrated a basalt breccia with a minimum thickness of 10 meters. This layer prevented further drilling. The weak reflection on the sonobuoy profile (reflector 4) corresponds to this bed. Shipboard measurements gave sonic velocities of about $6.0 \mathrm{~km} / \mathrm{sec}$ and density of about $2.9 \mathrm{~g} / \mathrm{cc}$ for the basalts. If the 

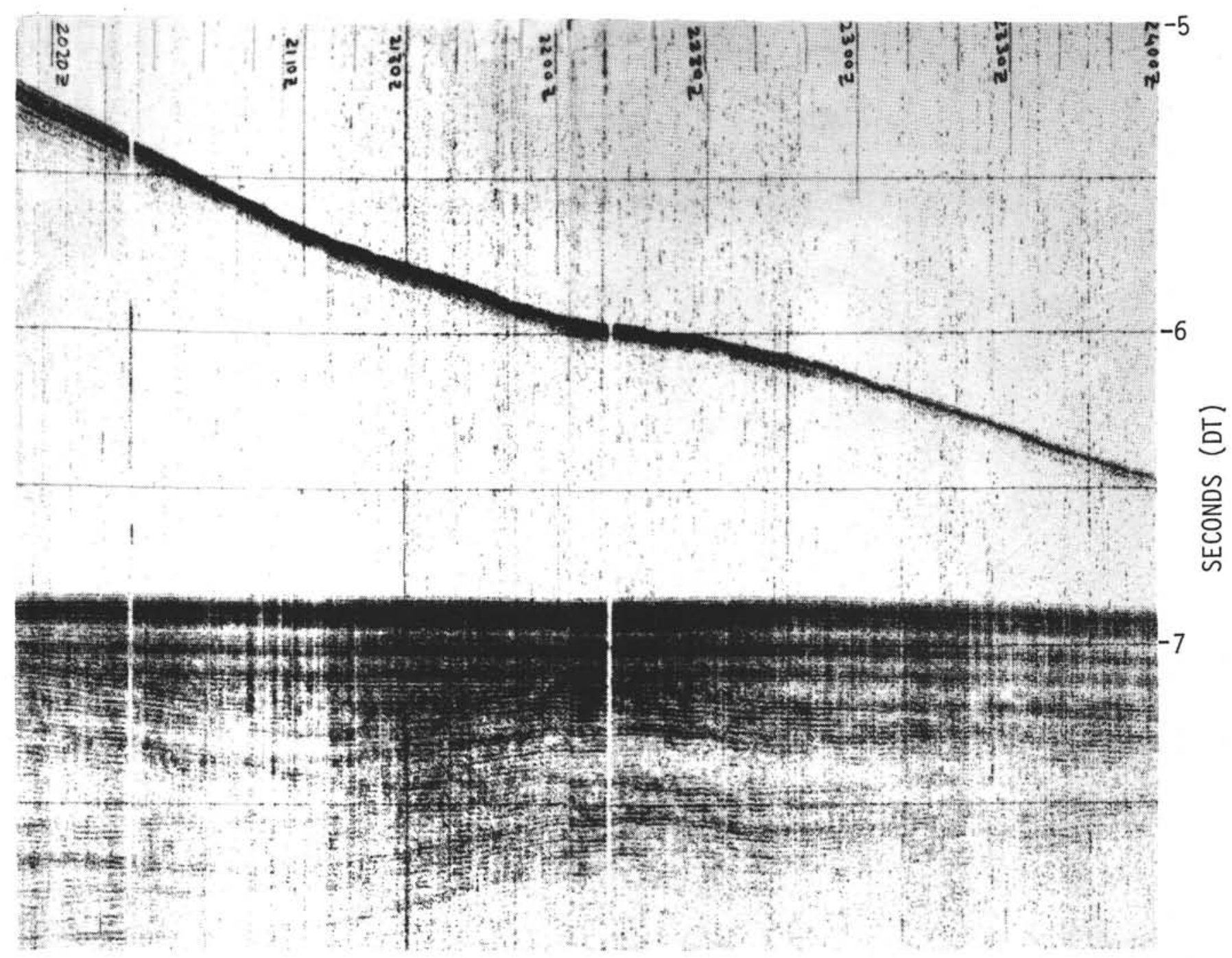

Figure 8. Sonobuoy profile obtained at Site 353.

entire layer between reflector 4 and basement consists of basalt breccia, clays, and sands, the average seismic velocity of this layer should range from 3.0 to 4.0 $\mathrm{km} / \mathrm{sec}$. Calculated depths to the basement for these velocities are given in Table 7.

The basalt breccia may be one of the reasons for the basal transparent layer near the slope of the trench.

\section{SUMMARY AND CONCLUSIONS}

\section{Drilling Into Lower Oceanic Crust}

We did not achieve at Site 353 the main objective of drilling close to the northern wall of the Vema Fracture Zone-namely, to obtain a section of the oceanic lower crust. The first attempt (Hole 353) was interrupted by a mechanical failure when we had penetrated to about 400 meters below the sea floor; basement had not yet been reached. The other two attempts (Holes 353A and 353B), made closer to the wall, terminated in a layer of basalt fragments or cobbles. A serious effort to go through this basalt cobble layer (with cementation of the hole, etc.) was not possible, because we had not enough time.
The basalt cobbles probably represent talus material, which originated from the basalt flows constituting the upper kilometer or so of the exposed crustal section on the northern wall of the fracture zone. Because of the relative freshness of the samples (suggested also by their high acoustic velocities) and because of their "olivine tholeiite" mineralogy (typical of basalts from oceanic spreading ridges), these basalts must have been originally emplaced at the northern axial segment of the Mid-Atlantic Ridge, roughly $30-40 \mathrm{~km}$ to the east of the drilling site (Figure 2). Assuming a spreading rate of 1.2 $\mathrm{cm} / \mathrm{yr}$ for this area (van Andel et al., 1971), we estimate the basalt to be roughly $3 \mathrm{~m}$.y. old. These basalts have characteristics indicating that they do not represent "leaky" intra-offset alkali-basalt volcanism.

Dredge hauls collected from the slopes of the northern wall in the vicinity of the site indicate that serpentinized peridotites are exposed on the wall. These dredged hauls are from Station A-II-20-8 (Melson and Thompson, 1971), about $5 \mathrm{~km}$ west of the drill site, and Station P7003-09 (Bonatti and Honnorez, 1975), about $30 \mathrm{~km}$ west of the site. Given the presence of serpentinite on the wall, it is surprising that no fragments of 


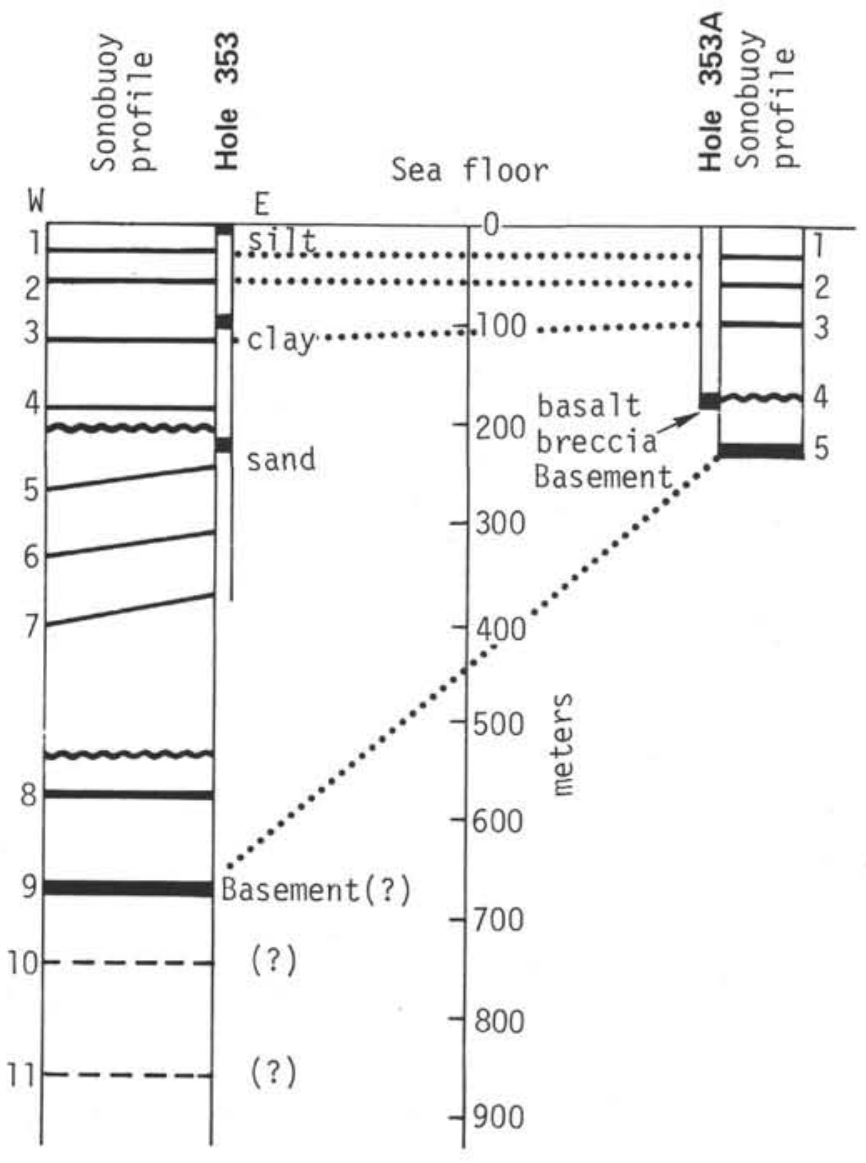

Figure 9. Comparison of the drilling results and seismic reflection data at Holes 353 and $353 \mathrm{~A}$. serpentinite or other plutonic rocks were found in the talus material drilled at Site 353 . A possible explanation is that the talus from the upper basaltic portion of the northern wall is fed preferentially to the transverse valley along south-facing shallow channels or "canyons." Some indication of such shallow channels can be seen in the topographic map (van Andel et al., 1971) of the area under discussion. It is possible, therefore, that the talus material is not evenly distributed along the foot and the lower part of the slope, but is thicker beneath the channels and thin or absent away from the channels. A similar situation is common on land when talus is formed along steep slopes. Our interpretation, if correct, would indicate that the drilling took place in an area beneath the exit of one of the channels feeding talus to the Vema transverse valley.

These considerations suggest that the original objective of drilling at Site 353 , i.e., to obtain a section of the lower oceanic crust by bypassing the upper crustal basaltic layer in the Vema Fracture Zone, is still a realistic objective, despite our failure to accomplish it during Leg 39.

\section{Sedimentation in the Vema Tranverse Valley}

Data obtained from examination of the sediments cored at Site 353 confirm an earlier conclusion derived from Site 26 data (DSDP Leg 4): the Vema transverse valley contains a thick sequence of Pleistocene turbidites. The cores consist mainly of alternating terrigenous sands and silty muds, commonly with graded bedding, which contain a fossil assemblage (planktonic and benthic foraminifers and calcareous

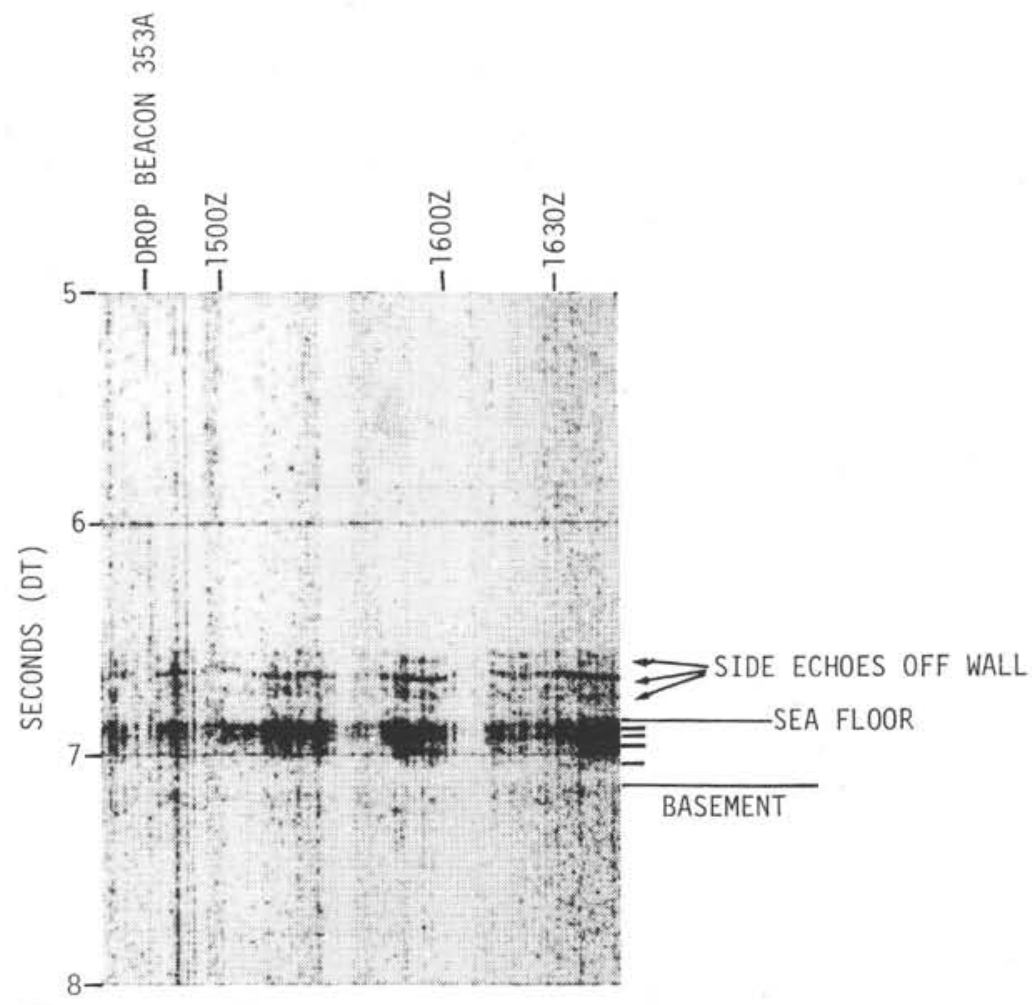

Figure 10. Reflection profile from tethered sonobuoy, Hole $353 \mathrm{~A}$. 
nannofossils) of Pleistocene age; the assemblage shows signs of redeposition and dissolution. The mineralogy of the clastics suggests the Amazon Cone, some $500 \mathrm{~km}$ away, as the source of the turbidites. The estimated deposition rate for some sections of the turbidite sequence is around $70 \mathrm{~cm} / 1000 \mathrm{yr}$ - unusually high even for turbidite deposits, especially considering that the source region is more than $500 \mathrm{~km}$ away.

The presence of a mineral such as olivine and grains of basaltic glass in sediments from Site 353 indicates that a minor but significant fraction of the sediment derives locally from the walls of the Vema transverse valley. That a significant fraction of deposits from within the large offset zones is provided by local source is clearly evident at the Romanche Fracture Zone (Bonatti et al., 1973). In the case of the Vema Fracture Zone, the local contribution is quantitatively minor, because it is highly diluted by the rapidly accumulating terrigenous turbidite deposits. In fact, no indication of such locally derived components was reported in connection with sediment cored at Site 26 (DSDP Leg $4)$, close to the axis of the Vema transverse valley.

\section{REFERENCES}

Bader, R.G., Gerard, R.D., et al., 1970. Initial Reports of the Deep Sea Drilling Project, Volume 4: Washington (U.S. Government Printing Office).

Bennett, R.H. and Keller, G.H., 1973. Physical properties evaluation. In van Andel, T.H., Heath, G.R., et al., Initial Reports of the Deep Sea Drilling Project, Volume 16: Washington (U.S. Government Printing Office), p. 513521.

Berger, W.H., 1972. Deep sea carbonates: Dissolution facies and age-depth constancy; Nature, v. 236, p. 392.

Berggren, W.A., 1972. A Cenozoic time-scale-some implications for regional geology and paleobiogeography: Lethaia, v. 5, p. 195-215.

Bonatti, E., 1973. Origin of offsets of the Mid-Atlantic Ridge in fracture zones: J. Geology, v. 81, p. 144-156.

Bonatti, E., Honnorez, J., and Ferrara, G., 1971. Peridotitegabbro-basalt complex from the equatorial Mid-Atlantic Ridge: Phil. Trans. Roy. Soc. London, ser. A, v. 268, p. $185-402$.

Bonatti, E. Honnorez, J., and Gartner, S., 1973. Sedimentary serpentinites from the equatorial Mid-Atlantic Ridge: J. Sed. Petrol., v. 43, p. 728-736.

Damuth, J.E. and Fairbridge, R.W., 1970. Equatorial Atlantic deep-sea arkosic sands and ice-age aridity in tropical South America: Geol. Soc. Am. Bull., v. 81, p. 189-206.
Damuth, J.E. and Kumar, N., 1975. Amazon Cone: Morphology, Sediments, Age and Growth Pattern: Geol. Soc. Am. Bull., v. 86, p. 863-878.

Fisher, D.E., 1975. Geoanalytic applications of particle tracks: Earth-Sci. Rev., v. 11, p. 291-335.

Fleischer, R.L. and Price, P.B., 1964. Techniques for geological dating of minerals by chemical etching of fission fragment tracks: Geochim. Cosmochim. Acta, v. 28, p. $1705-1714$.

Gartner, S., 1973. Absolute chronology of the late Neogene calcareous nannofossil succession in the equatorial Pacific: Geol. Soc. Am. Bull., v. 84, p. 2021-2034.

Gibbs, R.J., 1967. The geochemistry of the Amazon River system: Part I. The factors that control the salinity and the composition and concentrations of the suspended solids: Geol. Soc. Am. Bull., v. 78, p. 1203-1232.

Hay, W.W., 1970. Calcareous nannofossils from cores recovered on Leg 4. In Bader, R.G., Gerard, R.D., et al., Initial Reports of the Deep Sea Drilling Project, Volume 4: Washington (U.S. Government Printing Office), p. 455503.

Honnorez, J., Bonatti, E., Emiliani, C., Brönnimann, P., Furrer, M.A., and Myerhoff, A.A., 1975. Mesozoic limestone from Vema Offset Zone, Mid-Atlantic Ridge?: Earth Planet. Sci. Lett.. v. 26, p. 8-12.

McGeary, D.F.R., 1969. Sediments of the Vema Fracture Zone: unpublished Ph.D. thesis, Scripps Institution of Oceanography.

Melson, W.G. and Thompson, G., 1971. Petrology of a transform fault zone and adjacent ridge segments: Phil. Trans. Roy. Soc. London, Ser. A, v. 268, p. 423-441.

Milliman, J.D., Summerhayes, C.P., and Barretto, H.T., 1975. Quaternary sedimentation on the Amazon Continental Margin: A model: Geol. Soc. Am. Bull., v. 86, p. $610-614$.

Pimm, A.C., Garrison, R.E., and Boyce, R.E., 1971. Sedimentological synthesis: lithology, chemistry, and physical properties of sediments in the northwestern Pacific Ocean. In Fischer, A.G., Heezen, B.C., et al., Initial Reports of the Deep Sea Drilling Project, Volume 6: Washington (U.S. Government Printing Office), p. 11311252.

Robb, J.M. and Kane, M.F., 1975. Structure of the Vema Fracture Zone from gravity and magnetic intensity profiles: J. Geophys. Res., v. 80, p. 4441-4446.

van Andel, Tj. H., Corliss, J.B., and Bowen, V.T., 1967. The intersection between the Mid-Atlantic Ridge and the Vema Fracture Zone in the North Atlantic: J. Marine Res., v. 25, p. 343.

van Andel, Tj. H., Von Herzen, R.P., and Phillips, J.D., 1971. The Vema Fracture Zone and the tectonics of transverse shear zones in oceanic crustal plates: Marine Geophys. Res., v. 1, p. 251-283. 
APPENDIX A

Smear-slide Summary

\begin{tabular}{|c|c|c|c|c|c|c|c|c|c|c|c|c|c|c|c|c|c|c|c|c|c|c|}
\hline & $\begin{array}{l}\text { एँ } \\
\text { מू }\end{array}$ & 芦 & बु & 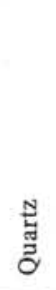 & 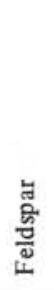 & $\frac{\text { 巳ூ }}{\Sigma}$ & 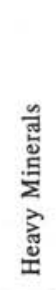 & 胥 & 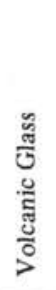 & 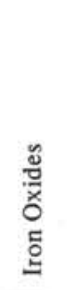 & 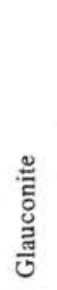 & $\stackrel{\Xi}{\rightleftarrows}$ & 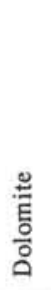 & \begin{tabular}{l}
$\stackrel{\Xi}{\Xi}$ \\
\multirow{N}{*}{}
\end{tabular} & 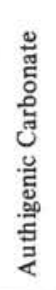 & 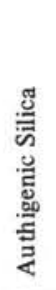 & 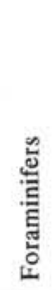 & 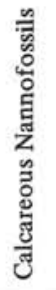 & 芯 & 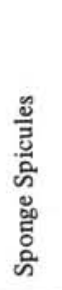 & 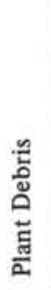 & Remarks \\
\hline \multicolumn{23}{|l|}{ Hole 353} \\
\hline $1, \mathrm{CC}$ & 45 & 35 & 20 & 35 & 15 & 5 & 10 & 15 & 1 & 5 & 10 & 5 & & & & & & 1 & & 1 & 1 & \\
\hline $2-1,118$ & 85 & 10 & 5 & 40 & 10 & - & 20 & 5 & - & - & 5 & 15 & & & & & 1 & 5 & & & & \\
\hline $2-1,130$ & - & - & - & - & - & - & - & - & - & 100 & - & - & & & & & & & & & & limonite nodule \\
\hline $2-1,131$ & & 50 & 50 & 40 & & 5 & 10 & 30 & & 5 & 5 & 5 & & & & & & & & & & \\
\hline $2-1,136$ & & 50 & 50 & 10 & 1 & 5 & 10 & 65 & & 5 & & 5 & & 1 & & & & & & & & \\
\hline $2-2,25$ & & 10 & 90 & 10 & & & 5 & 70 & & 5 & & & & & & & & 10 & 1 & & & \\
\hline $2-2,30$ & 10 & 20 & 70 & & & & & 10 & & & 1 & & & & 20 & & 5 & 60 & 5 & & & \\
\hline $2-2,55$ & 10 & 30 & 60 & & & & & 25 & & 5 & 1 & 5 & & & 30 & & 5 & 25 & 5 & & & \\
\hline $2-2,69$ & & & & & & & & & & 100 & & & & & & & & & & & & \\
\hline $2-3,50$ & 10 & 30 & 60 & 10 & & 1 & 1 & 35 & & 5 & 1 & 5 & & & 10 & & & 30 & 5 & & & \\
\hline $2, \mathrm{CC}$ & 10 & 30 & 60 & 5 & 1 & 1 & 1 & 35 & & 5 & 1 & 10 & & & 15 & & 1 & 30 & 1 & 1 & & \\
\hline $3-1,142$ & 50 & 40 & 10 & 40 & 10 & 5 & 20 & & & & 10 & & & & 10 & & 5 & & & & & \\
\hline $3-2,30$ & 80 & 15 & 5 & 50 & & 1 & 15 & & & & 5 & & & & 10 & 5 & & 5 & & & & \\
\hline $3-2,134$ & 95 & 5 & & 80 & & & 5 & & & & & 10 & & & & 5 & & & & & & \\
\hline $3-2,145$ & 5 & 35 & 60 & 35 & & 1 & 5 & 30 & & 5 & 5 & 5 & & & 1 & 15 & 1 & 10 & & & & \\
\hline $3, \mathrm{CC}$ & 5 & 55 & 40 & 20 & & 5 & 1 & 30 & & 10 & 5 & 15 & & & 1 & & 1 & 15 & & & & \\
\hline \multicolumn{23}{|c|}{ Hole 353A } \\
\hline $1-1,20$ & 10 & 30 & 60 & 10 & 1 & & & 30 & & 5 & & 5 & & & 25 & & 5 & 20 & 1 & 1 & & \\
\hline $1-1,25$ & 10 & 30 & 60 & 5 & & 1 & 1 & 15 & & & 1 & & & 1 & 25 & & 1 & 45 & & & & \\
\hline $1-1,34$ & 10 & 30 & 60 & 5 & & 1 & 5 & 20 & & 10 & 5 & 5 & & & 20 & & 1 & 30 & 1 & & & \\
\hline $1-145$ & & 10 & 90 & 10 & & & 5 & 60 & & 10 & & 5 & & 10 & & & & & & & & \\
\hline $1-1,66$ & 10 & 20 & 70 & 15 & & 1 & 5 & 20 & & 5 & & 5 & & 10 & 10 & & & 30 & & & & \\
\hline $1-1,115$ & & 50 & 50 & 20 & 1 . & 5 & 10 & 5 & & 5 & 5 & 5 & 1 & 5 & 5 & & 5 & 25 & & & 1 & \\
\hline $1-1,132$ & & 35 & 65 & 5 & & 5 & 5 & 25 & & 5 & & & & & 25 & & 5 & 25 & 1 & & & \\
\hline $1-2,8$ & 10 & 30 & 60 & 15 & & 5 & 5 & 15 & & 5 & 5 & 5 & & 5 & 5 & & 5 & 30 & & 1 & & $=$ \\
\hline $1-2,31$ & 10 & 20 & 70 & 1 & & & 1 & 5 & & & & & & 5 & 40 & & 10 & 40 & & & & 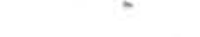 \\
\hline $1-2,37$ & 10 & 30 & 60 & 25 & 5 & 5 & & & & 5 & & 5 & & & 5 & & 5 & 40 & & & & \\
\hline $1-2,43$ & 10 & 30 & 60 & 5 & 1 & & & 20 & & & & 5 & & & 10 & & 20 & 40 & & & & \\
\hline $1-2,102$ & 10 & 20 & 70 & 10 & & 1 & 1 & 15 & & 5 & & 5 & & 1 & 10 & & 1 & 55 & & & & \\
\hline $1-2,139$ & 100 & & & 70 & 5 & 1 & 5 & & & & 15 & 5 & & & & & & & & & & \\
\hline $1, \mathrm{CC}$ & 40 & 40 & 20 & 35 & 5 & 5 & 5 & 20 & & 5 & 5 & & & 1 & & & & 20 & & & & \\
\hline
\end{tabular}

APPENDIX B

Carbonate and Quartz Determinations

\begin{tabular}{ccccc}
\hline $\begin{array}{c}\text { Sediment } \\
\text { Depth } \\
\text { Section }\end{array}$ & $\mathrm{CaCO}_{3}$ & $\begin{array}{c}\text { Org } \\
(\%)\end{array}$ & $\begin{array}{c}\text { Total } \\
\text { Carb } \\
(\%)\end{array}$ \\
\hline
\end{tabular}

Hole 353

$\begin{array}{lllll}2-2 & 12030 & 4.75 & 0.36 & - \\ 2-2 & 12115 & 3.32 & 0.43 & 0.83 \\ 2-3 & 12249 & 3.32 & 0.48 & 0.87 \\ 3-2 & 26360 & 0.76 & 0.13 & 0.22 \\ 3-2 & 26375 & 0.15 & 0.09 & 0.11 \\ 3-2 & 26384 & 2.91 & 0.34 & 0.69\end{array}$

Hole 353A

\begin{tabular}{lllll}
$1-1$ & 102 & 4.25 & 0.48 & $-\overline{7}$ \\
$1-1$ & 201 & 3.25 & 0.59 & 0.98 \\
\hline
\end{tabular}



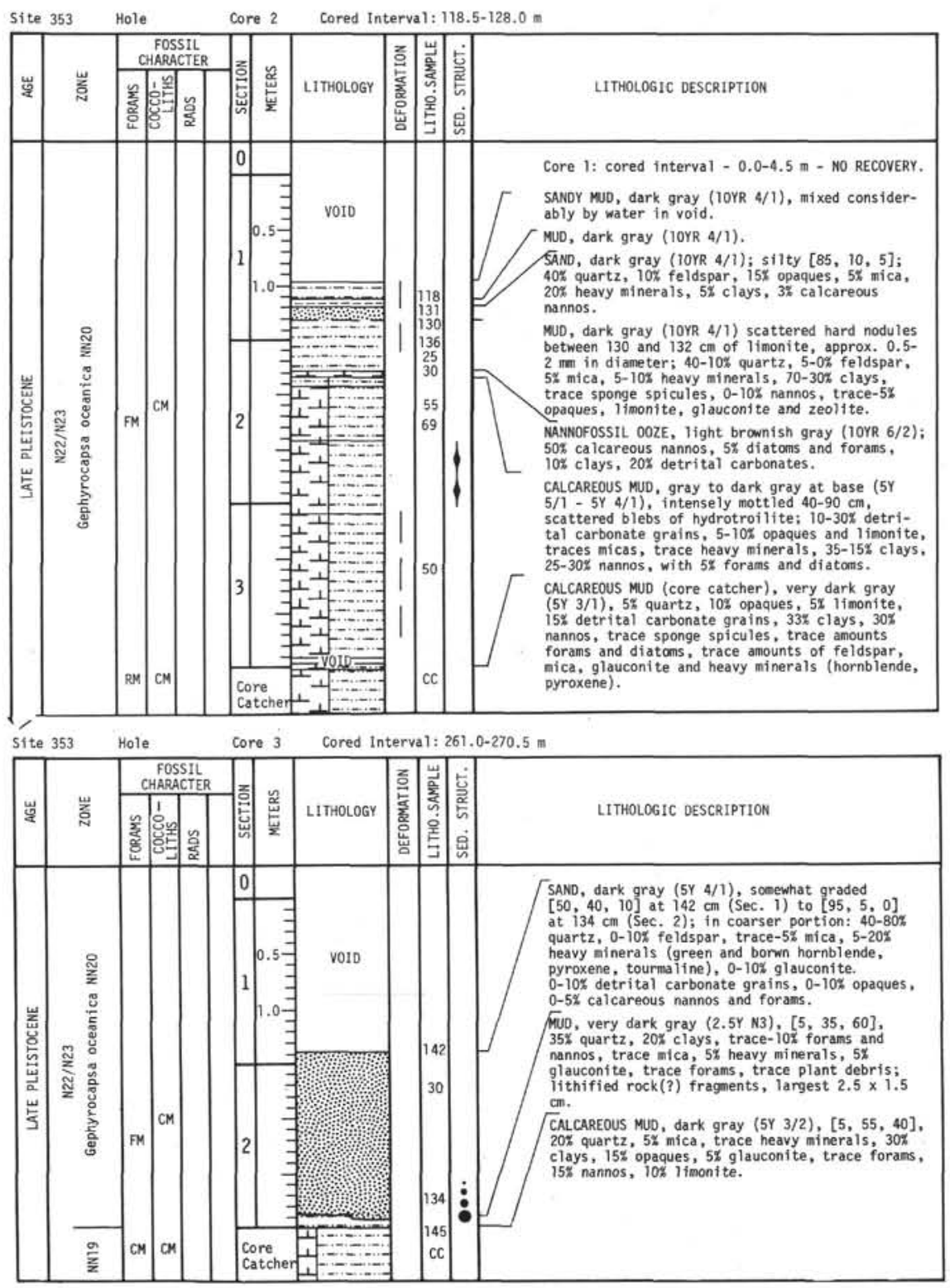

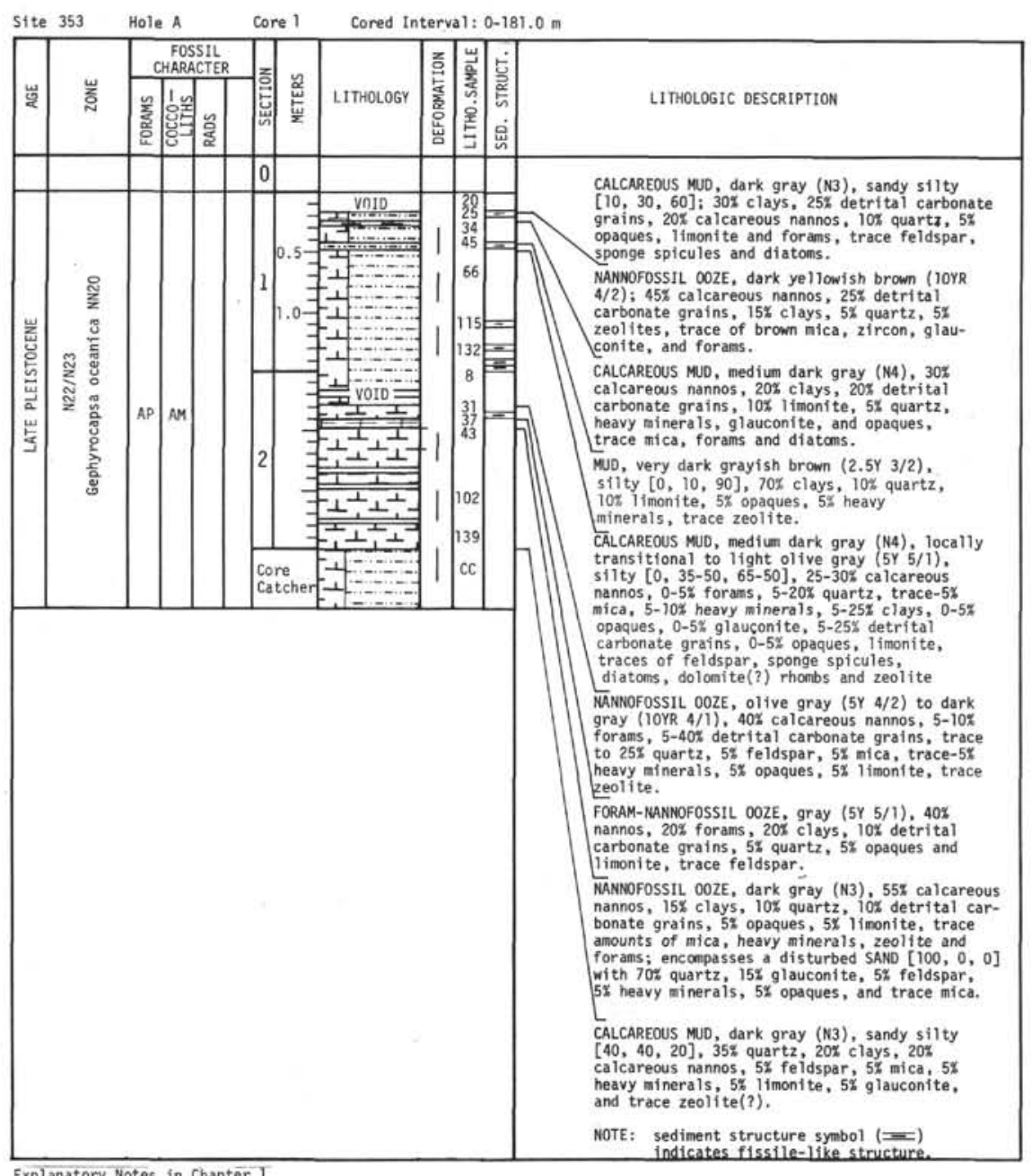

Explanatory Notes in Chapter I 


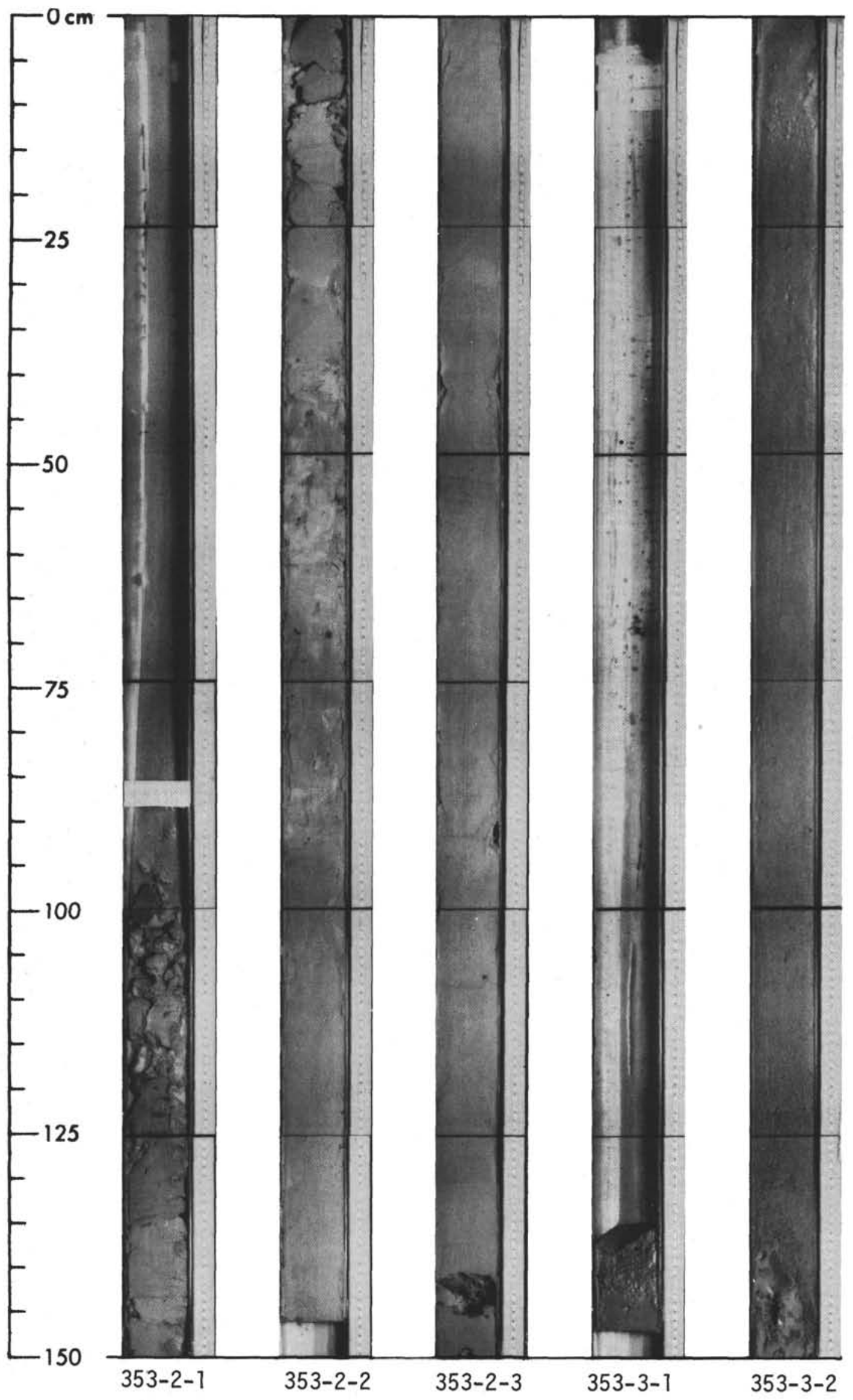




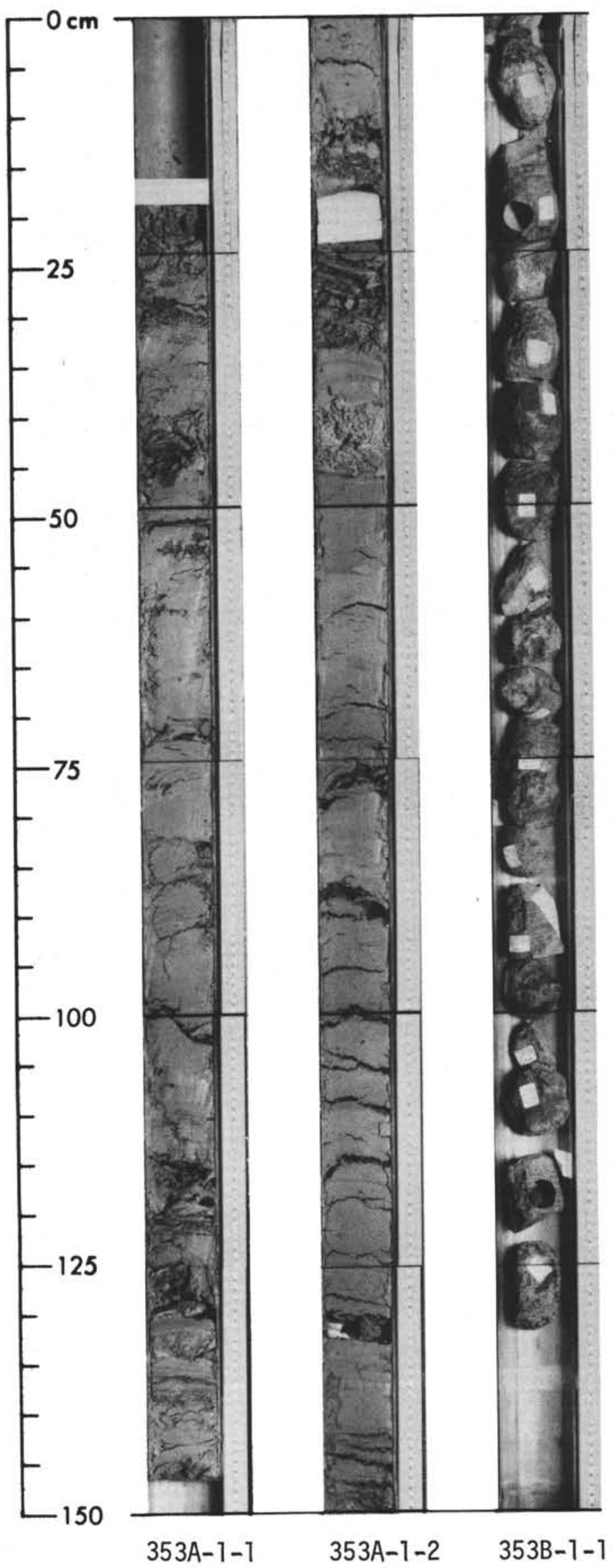

